Article

\title{
Geochemistry and Genesis of Beryl Crystals in the LCT Pegmatite Type, Ebrahim-Attar Mountain, Western Iran
}

\author{
Narges Daneshvar ${ }^{1}\left(\mathbb{D}\right.$, Hossein Azizi $^{1, *(\mathbb{D})}$, Yoshihiro Asahara ${ }^{2} \mathbb{D}$, Motohiro Tsuboi ${ }^{3}$, Masayo Minami $^{4}$ \\ and Yousif O. Mohammad ${ }^{5}$ (D)
}

1 Department of Mining Engineering, Faculty of Engineering, University of Kurdistan, Sanandaj 66177-15175, Iran; daneshvar_n@yahoo.com

2 Department of Earth and Environmental Sciences, Graduate School of Environmental Studies, Nagoya University, Nagoya 464-8601, Japan; asahara@eps.nagoya-u.ac.jp

3 Department of Applied Chemistry for Environment, School of Biological and Environmental Sciences, Kwansei Gakuin University, Sanda 669-1337, Japan; tsuboimot@kwansei.ac.jp

4 Division for Chronological Research, Institute for Space-Earth Environmental Research, Nagoya University, Nagoya 464-8601, Japan; minami@isee.nagoya-u.ac.jp

5 Department of Geology, College of Science, Sulaimani University, Sulaimani 46001, Iraq; yousif.mohammad@univsul.edu.iq

* Correspondence: azizi1345@gmail.com; Tel.: +98-918-872-3794

check for updates

Citation: Daneshvar, N.; Azizi, H.; Asahara, Y.; Tsuboi, M.; Minami, M.; Mohammad, Y.O. Geochemistry and Genesis of Beryl Crystals in the LCT Pegmatite Type, Ebrahim-Attar Mountain, Western Iran. Minerals 2021, 11, 717. https://doi.org/ $10.3390 / \min 11070717$

Academic Editor:

Massimo D'Antonio

Received: 15 May 2021

Accepted: 28 June 2021

Published: 2 July 2021

Publisher's Note: MDPI stays neutral with regard to jurisdictional claims in published maps and institutional affiliations.

Copyright: (c) 2021 by the authors. Licensee MDPI, Basel, Switzerland. This article is an open access article distributed under the terms and conditions of the Creative Commons Attribution (CC BY) license (https:// creativecommons.org/licenses/by/ $4.0 /)$.

\begin{abstract}
Ebrahim-Attar granitic pegmatite, which is distributed in southwest Ghorveh, western Iran, is strongly peraluminous and contains minor beryl crystals. Pale-green to white beryl grains are crystallized in the rim and central parts of the granite body. The beryl grains are characterized by low contents of alkali oxides $\left(\mathrm{Na}_{2} \mathrm{O}=0.24-0.41\right.$ wt. $\%, \mathrm{~K}_{2} \mathrm{O}=0.05-0.17$ wt. $\%, \mathrm{Li}_{2} \mathrm{O}=0.03-0.04$ wt. $\%$, and $\mathrm{Cs}_{2} \mathrm{O}=0.01-0.03$ wt.\%) and high contents of $\mathrm{Be}_{2} \mathrm{O}$ oxide (10.0 to $\left.11.9 \mathrm{wt} . \%\right)$. The low contents of alkali elements (oxides), low $\mathrm{Na} / \mathrm{Li}$ (apfu) ratios (2.94 to 5.75), and variations in iron oxide $(\mathrm{FeO}=0.28-1.18 \mathrm{wt} . \%)$ reveal a poorly evolved magmatic source of the beryl grains. Low abundances of rare earth elements $(\Sigma \mathrm{REE}=0.8-4.9 \mathrm{ppm})$ with high ${ }^{87} \mathrm{Sr}^{/ 86} \mathrm{Sr}_{(\mathrm{i})}$ ratios of $0.739 \pm 0.036$ for the beryl grains and 0.7081 for the host granites infer that the primary magma was directly produced by partial melting of the upper continental crust (UCC). The crystallization temperature of the Ebrahim-Attar granitic pegmatite changes from 586 to $755{ }^{\circ} \mathrm{C}$ (average $=629{ }^{\circ} \mathrm{C}$ ), as calculated based on the zircon saturation index. Furthermore, the quartz geobarometer calculation shows that crystallization occurred at pressures of approximately 233-246 MPa. This pressure range is a promising condition for saturation of Be in magma. During granitic magma crystallization, the melt was gradually saturated with $\mathrm{Be}$, and then beryl crystallized in the assemblage of the main minerals such as quartz and feldspar. Likewise, the host granite is characterized by high ratios of $\mathrm{Nb} / \mathrm{Ta}$ (4.79-16.3) and Zr/Hf (12.2-19.1), and peraluminous signatures are compatible with Be-bearing LCT (Li-Ce and Ta) pegmatites.
\end{abstract}

Keywords: beryl geochemistry; Be-bearing granite; partial crustal melting; Sanandaj-Sirjan zone

\section{Introduction}

Beryllium (Be), with an atomic number of 4 and an ionic radius of approximately $0.27 \AA$, is the lightest alkaline-earth element on Earth [1] and belongs to the rare lithophile elements group (RLE) [2]. Therefore, it is mainly concentrated in the upper continental crust (1.9-3.1 ppm; [3]), especially in peraluminous granites, alkaline rocks, and granitic pegmatites $[2,3]$. Beryllium $\left(\mathrm{Be}^{2+}\right)$ has a radius that is too small in tetrahedral coordination and cannot enter the crystal lattice of the main rock forming minerals such as quartz, feldspar, biotite, and muscovite [2]. Therefore, it tends to produce distinct minerals such as beryl [3]. Beryl $\left(\square, \mathrm{Na}, \mathrm{Cs}, \mathrm{H}_{2} \mathrm{O}\right)(\mathrm{Al}, \mathrm{Sc}, \mathrm{Fe}, \mathrm{Mg})_{2}(\mathrm{Be}, \mathrm{Li})_{3}\left(\mathrm{Si}_{6} \mathrm{O}_{18}\right)$ is the main beryllium mineral produced in a few geological settings: (1) highly evolved S-type granites and granitic 
pegmatite [3]; (2) hydrothermal deposits related to granite (e.g., greisen); (3) volcanogenic hosted beryllium deposits [3]; (4) metamorphic rock, specifically emerald-bearing schist [4]; (5) carbonate-hosted beryllium deposit [3,5]. Meanwhile, bertrandite $\left(\mathrm{Be}_{4} \mathrm{Si}_{2} \mathrm{O}_{7}(\mathrm{OH})_{2}\right)$ and phenakite $\left(\mathrm{Be}_{2} \mathrm{SiO}_{4}\right)$ are dominant and related to volcanic and carbonate-hosted deposits [3,6]. Three main classes of beryllium ore deposits, volcanogenic, carbonatehosted deposits (bertrandite and/or phenakite), and granitic pegmatite (beryl) deposits, are distributed worldwide $[3,7,8]$.

Beryl shows various colors because of the different contents of $\mathrm{Cr}, \mathrm{V}, \mathrm{Mn}$, and Fe in the mineral structure $[5,9,10]$. Thus, the color of beryl ranges from green $\left(\mathrm{Cr}^{3+}, \pm \mathrm{V}^{3+}\right.$; emerald) to yellow $\left(\mathrm{Fe}^{2+}\right.$; heliodor), light blue $\left(\mathrm{Fe}^{3+}\right.$; aquamarine), sea-green $\left(\mathrm{Fe}^{2+}\right.$ and $\mathrm{Fe}^{3+}$; beryl), pink $\left(\mathrm{Mn}^{2+} ;\right.$ morganite), red $\left(\mathrm{Mn}^{3+} ;\right.$ red beryl), colorless (goshenite), and white $[5,11,12]$. Beryl is traded as a precious and semiprecious mineral and can be used in alloys, nuclear reactors, and space shuttles $[4,13]$.

The chemical composition of beryl could be useful to understand the evolution of granitic pegmatite [14]. The concentrations of alkali elements ( $\mathrm{Na}, \mathrm{Li}$, and $\mathrm{Cs}$ ) and divalent elements (Fe, Mg) are important for understanding the geochemical signatures of the host granitic pegmatite $[11,14,15]$. The temperature and composition of magma generally control the solubility of Be in the melt [16]. Be has low solubility in magma with high alumina at low temperatures [16]. Consequently, volatility has a critical role in increasing the solubility of $\mathrm{Be}$, which has high solubility in melts that are rich in $\mathrm{H}_{2} \mathrm{O}, \mathrm{Li}, \mathrm{P}, \mathrm{F}$, and B [17]. Therefore, a high concentration of Be shows magmatic $[18,19]$ or hydrothermal sources $[20,21]$.

As mentioned above, there are several geological settings, but herein, we focus on granitic pegmatite. Beryl is the main beryllium-bearing phase and is formed during the late stage of granite melts with high abundances of Li, Cs, and Ta, which is called LCT pegmatite [22,23]. Most LCT pegmatites have peraluminous signatures that are determined by the melting of pelitic rocks related to the thickness of the continental crust during collision [24] to a postcollisional tectonic regime [25].

Some beryl-bearing pegmatites have been reported in Iran, including Khajeh Morad in south Mashhad [26,27], Kamari-Zaman Abad-Dehno in south Hamedan [28,29], and Ebrahim-Attar in southwest Ghorveh [26,28,30-32] (Figure 1). The Ebrahim-Attar granitic pegmatite of Ghorveh district in the Sanandaj-Sirjan zone (SaSZ) is one of the most important semigemstone sources in Iran (Figure 2a). The granitic pegmatite is widely exposed in two nearby district areas called Ebrahim-Attar 1 and Ebrahim-Attar 2. It is an active feldspar mine and, to a lesser extent, mica and beryl [30].

Herein, we focus on the Ebrahim-Attar beryl-bearing granitic pegmatite because there is a lack of information on the source and geochemistry of beryl. Overall, a few studies have been published on host granite without focusing on the beryl chemistry, genesis, and economic value of this semiprecious mineral. Therefore, major oxides, trace elements including rare earth elements, and $\mathrm{Sr}$ isotopes are measured in the separated mineral beryl to provide detailed information about the genesis and mineralization of the mineral and its host rock. Detailed mapping, field observation, petrography, and chemical analysis of beryl grains were performed to characterize the mineralization properties. The goal of this study is to illustrate the crystal chemistry of beryl grains. We investigate the main process (magmatic/hydrothermal) that leads to the formation of semigemstone beryl mineralization and the geochemical signature of source melt based on beryl chemistry. Trace element abundances of the beryl grains can track the mineralization pathway and provide valuable information about the geochemical features of the parental granite melt. In this research, we report the chemical signatures of beryl crystals by measuring the major elements by applying XRF, trace elements including rare earth elements (REEs), and Sr isotope ratios using ICP-MS and TIMS for the first time and provide more accurate and precise data to evaluate the geochemical features of host granitic pegmatite and beryl mineralization, respectively. 


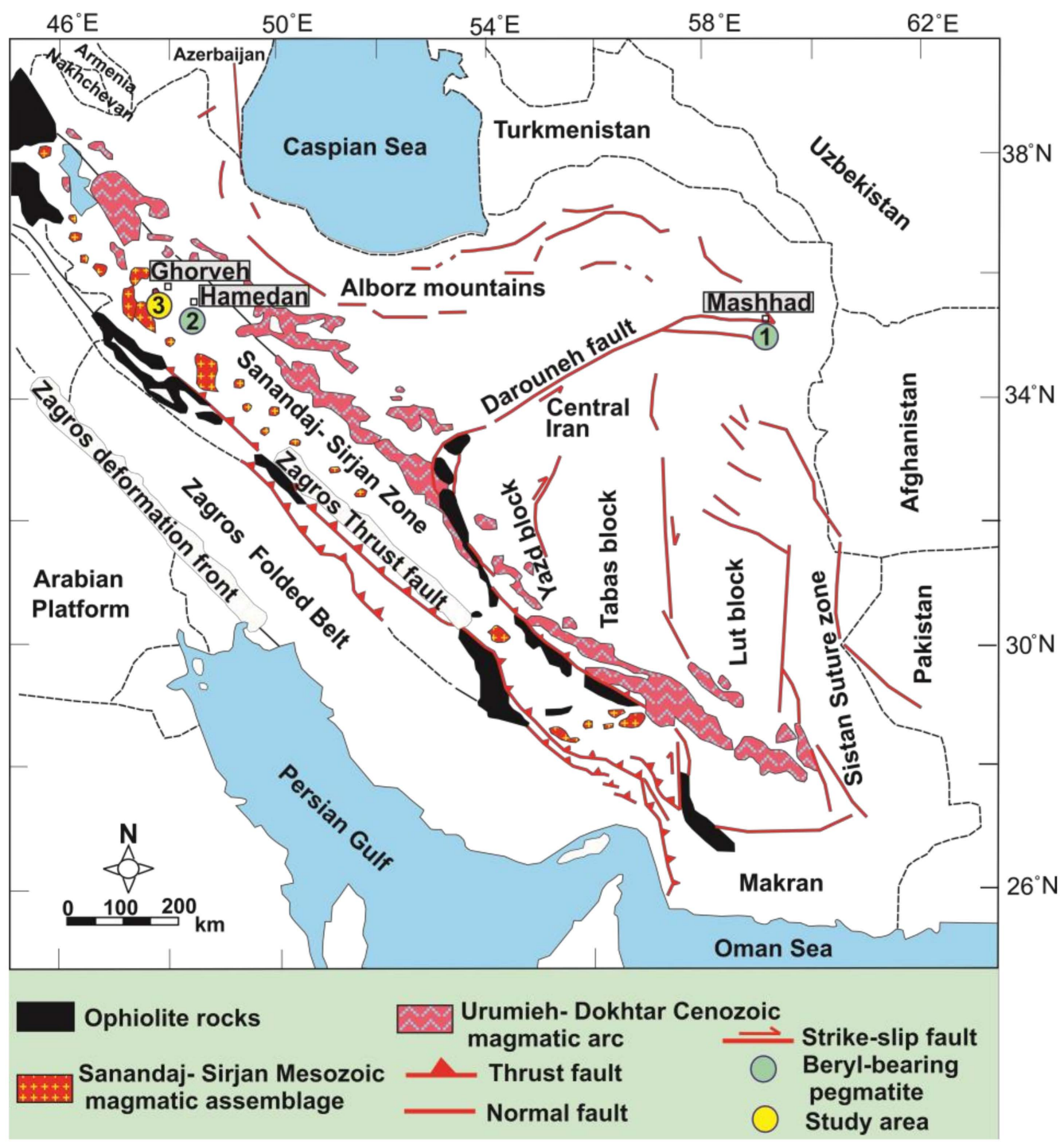

Figure 1. Structural map of Iran [33] with positions of beryl-bearing pegmatites including (1) Khajeh Morad [26,27], (2) Kamari and Zaman Abad [28,29], and (3) Ebrahim-Attar granitic pegmatite (this study).

\section{Geological Setting and Mineralogy}

The Sanandaj-Sirjan zone (SaSZ) is a metamorphic-magmatic belt in western Iran and has a width of 50-150 km and a length of $1200 \mathrm{~km}$ [33-35]. In the northern SaSZ, the Ghorveh district consists of a Jurassic metamorphic complex, a suite of greenschist, marble, amphibolite, and quartzite with several stages of deformation [30], and some igneous rock, aplite, and pegmatite with ages of 180-140 Ma intruded into the Jurassic metamorphic complex [36-39] (Figure 2a). The largest pegmatite outcrop is found in the Ebrahim-Attar Mountains in southwest Ghorveh, west of Iran (Figure 2b).

The Ebrahim-Attar Mountains contain a sequence of marble, schist, and metabasite, and granitic pegmatite occurs in the dolomitic layer. A small tungsten-bearing skarn zone occurs at their contact with a thickness of 1-2 $\mathrm{m}$ (Figures 1 and 2). This mountain is surrounded by the $157 \mathrm{Ma}$ Moshir Abad granite [38] in the north and the $157.9( \pm 1.6)$ Ma Ghalaylan granite in the south [36] as determined by zircon U-Pb dating. $\mathrm{Rb}-\mathrm{Sr}$ dating yielded an age of 102.5 $\pm 6.1 \mathrm{Ma}$ for the Ebrahim-Attar pegmatite [30] (Figure 2b). The predominant signatures of this pluton are highly peraluminous leucogranite with megacrysts of K-feldspar. The Ebrahim-Attar granite has been well documented mineralogically, geochemically, and isotopically by Azizi et al. [30]. 

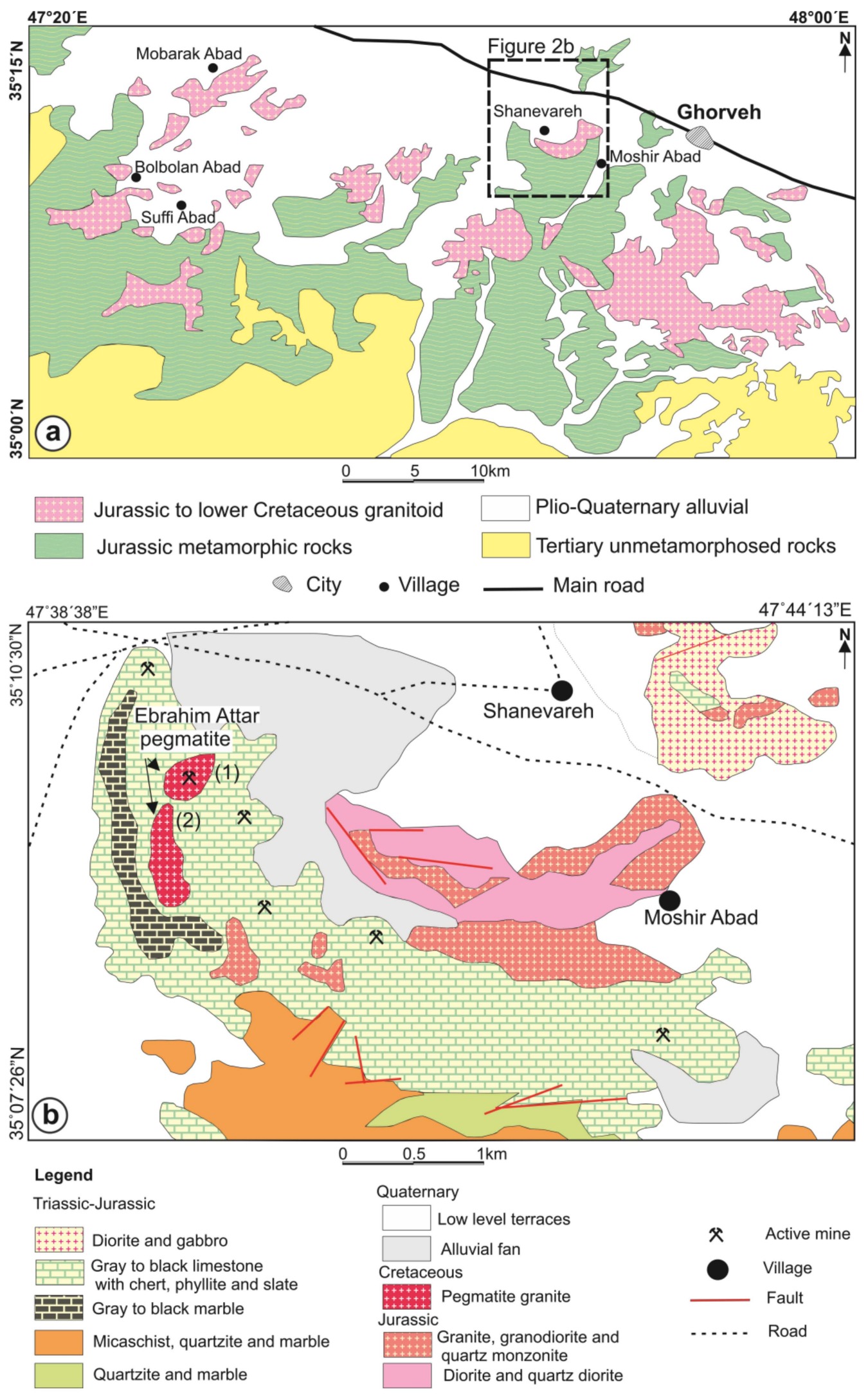

Figure 2. (a) Simplified geological map of the Ghorveh area based on 1:100,000 geological maps of Ghorveh, Songhor, and Sanandaj [40-42]. This shows that the Jurassic metamorphic complex is cut by various granites. (b) The geological map of the study area indicates that the Ebrahim-Attar granitic pegmatite cuts the Jurassic metamorphic rocks [41]. The Ebrahim-Attar pegmatite has two parts-1 and 2 . 
The Ebrahim-Attar granite cuts the Jurassic marble in the study area (Figure 3a). Minor skarn mineralization was observed in the contact. The granitic intrusion from the rim to the center varies from fine-grained leucogranite to coarse-grained pegmatite (Figure 3b,c). In the center, the crystal size ranges from millimeters to tens of centimeters (Figure $3 \mathrm{~d}-\mathrm{f}$ ). Although the Ebrahim-Attar rock is not a typically zoned pegmatite, based on our field observations, the mineral sequence and size of the crystals, it is divided into two subzones: (1) The thick border zone, which includes equigranular leucogranite. The mineralogy is mainly feldspar, quartz, and muscovite (Figure 3d). (2) The inner zone is marked with mineral sequences of large feldspar+quartz+muscovite with less biotite and tourmaline (Figure 3e). A graphic texture is observed in the inner pegmatite, and intergrowth of quartz and feldspar is identified in a hand specimen (Figure 3f). Overall, the mineral assemblage of both subzones 1 and 2 consists of quartz, alkali feldspar (orthoclase and microcline), plagioclase (albite), muscovite, tourmaline, and beryl [30,32] and the beryl grains appear in pale green color (Figure 4).
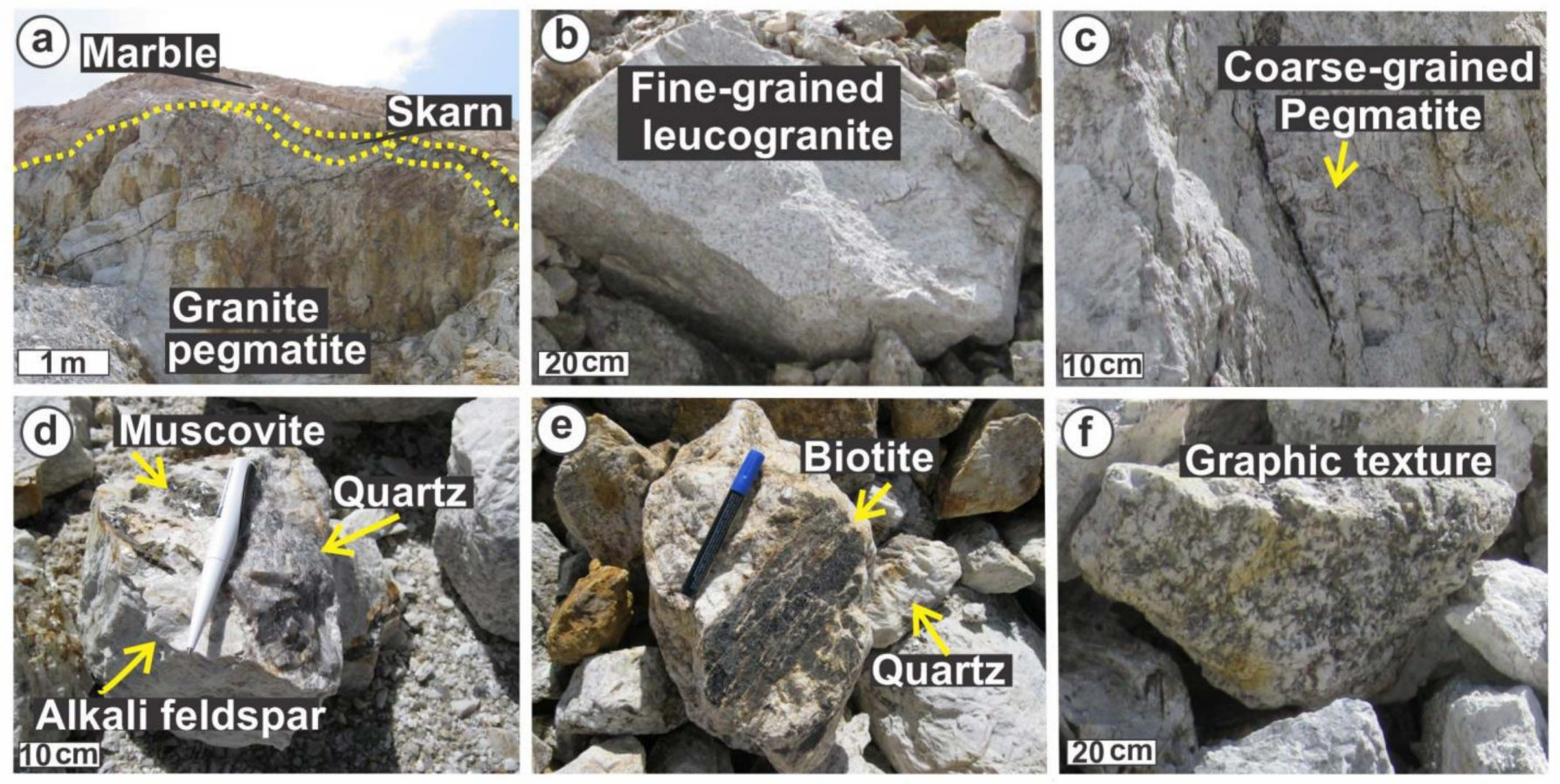

Figure 3. Photographs of the Ebrahim-Attar granitic pegmatite. (a) This pluton intruded into the Jurassic marble in the study area. (b,c) Size variation from the border (fine-grained) to the inner pegmatitic part (coarse-grained). (d,e) Megacrystals of the main mineral in the inner pegmatitic part, including large feldspar and muscovite, quartz, and less biotite. (f) Naked-eye graphic texture.

The compositions of major and trace elements and $\mathrm{Sr}$ and $\mathrm{Nd}$ isotopes of the Ebrahim-Attar granitic pegmatites are well documented by Azizi et al. (2016) [30] (Tables 1-3 in this reference). These rocks have characteristics with high $\mathrm{SiO}_{2}$ contents (71.4-81.0 wt.\%) and peraluminous signatures $(\mathrm{ASI}(\mathrm{A} / \mathrm{CNK})=1.0-1.2)$. The major oxide contents are $\mathrm{Al}_{2} \mathrm{O}_{3}=10.8-15.8 \mathrm{wt} . \%$, $\mathrm{K}_{2} \mathrm{O}=1.54$ to 5.59 wt. $\%, \mathrm{Na}_{2} \mathrm{O}=3.74-5.33$ wt. $\%, \mathrm{CaO}=0.33-1.73$ wt. $\%, \mathrm{Fe}_{2} \mathrm{O}_{3}=0.19-0.69$ wt. $\%$, $\mathrm{MnO}=0-0.02 \mathrm{wt} . \%$, and $\mathrm{MgO}=0.04-0.12 \mathrm{wt} . \%$. The Rb content ranges from 145 to $440 \mathrm{ppm}$, Sr from 7.30 to $37.4 \mathrm{ppm}$, and Zr from 9.3 to $108 \mathrm{ppm}$. The pegmatite samples indicate homogeneous REE patterns (Figure 5). The chondrite-normalized REE pattern shows a flat LREE trend with slightly enriched HREEs (Figure 5) and pronounced negative Eu anomalies $\left(\mathrm{Eu} / \mathrm{Eu}^{*}=0.01-0.14\right.$ and Figure 5). 


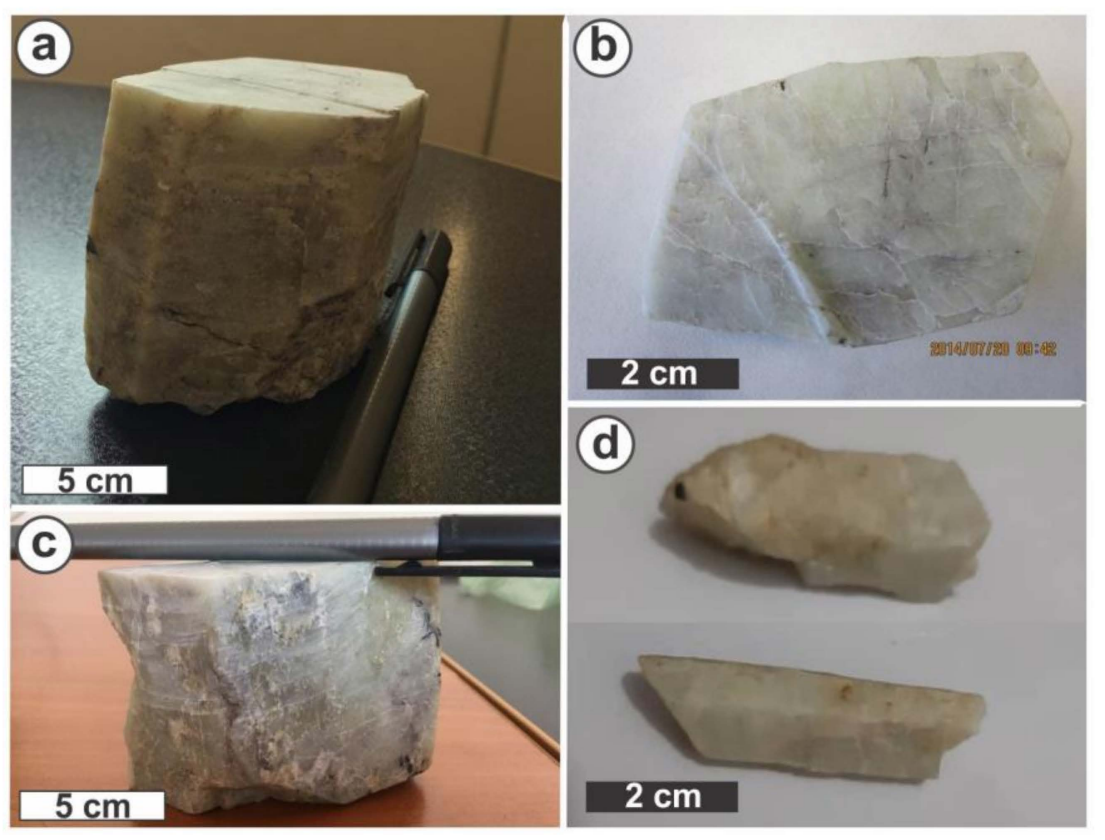

Figure 4. (a-d) Euhedral hexagonal prismatic crystal of beryl grains with pale-green to white colors in the Ebrahim-Attar granitic pegmatite.

The $\mathrm{Rb}-\mathrm{Sr}$ and $\mathrm{Sm}-\mathrm{Nd}$ analyses for the Ebrahim-Attar pegmatites are also presented by Azizi et al. [30]. The ${ }^{87} \mathrm{Sr} /{ }^{86} \mathrm{Sr}(\mathrm{i})$ ratios $(=0.7081),{ }^{143} \mathrm{Nd} /{ }^{144} \mathrm{Nd}_{(\mathrm{i})}(=0.5122)$, and $\varepsilon \mathrm{Nd}(\mathrm{t})$ $(=-5.8$ to -1.6$)$ were calculated based on $102 \mathrm{Ma}$.

The existence of beryl shows that the Ebrahim-Attar pegmatite was fertile [43]. The chemical compositions of the host rocks and the color of beryl are proper indicators of the fractionation degree of magma [43]. For example, less-evolved pegmatite has a low Ce concentration [31], and its beryl is green. Highly evolved pegmatite has a higher Cs content [32], and its beryl is white to pink. The Ebrahim-Attar pegmatite has low Cs content ( $\mathrm{Cs}=0.6-4.7 \mathrm{ppm})$, and its beryl is pale green, indicating that the beryl crystallized at a low rate of magma fractionation.

Large beryl crystals $(10-20 \mathrm{~cm})$ with euhedral and prismatic shapes and pale-green to white colors appear as mineral parageneses of quartz and feldspar in mega-crystals (Figure 4).

\section{Analytical Method}

In this research, ten homogeneous beryl grains from the pegmatite zone were separated, and seven fresh and unaltered crystals were selected for petrological and geochemical studies. The concentrations of major oxides and trace elements, including rare earth elements (REEs) and Sr isotope ratios, were measured in the selected grains in this research. Here, our analytical methods are briefly summarized below.

Approximately $10-20 \mathrm{~g}$ of each sample was powdered with an agate mill. First, $0.5 \mathrm{~g}$ of each sample powder was mixed with $5.0 \mathrm{~g}$ of lithium tetraborate, and a glass bead was prepared for XRF analysis. Major elements except Be were measured by WD-XRF (Rigaku ZSX Primus II) at Nagoya University (NU), Japan. For measurement of loss on ignition (LOI), $0.4 \mathrm{~g}$ of powder samples were taken in already-weighed quartz crucibles and heated at $1000{ }^{\circ} \mathrm{C}$ in a furnace for $6 \mathrm{~h}$. Based on the mass difference before and after heating, the values in weight percent of LOI were calculated for each sample.

For the quantitative analysis of beryllium (Be) and trace elements, including REEs, approximately $30 \mathrm{mg}$ of each sample was fused with $200 \mathrm{mg}$ of potassium fluoride (KF) in a platinum crucible at $1000{ }^{\circ} \mathrm{C}$ for $10 \mathrm{~min}$ at NU. A blank sample of $200 \mathrm{mg} \mathrm{KF}$ was also fused and prepared. After cooling, it was dissolved in $\mathrm{H}_{2} \mathrm{O}$, moved into an open PTFE beaker, and then dried. Next, several drops of concentrated $\mathrm{HNO}_{3}(68 \%)$ were added to the dried samples and dried again. To exclude the remaining silicon ( $\mathrm{Si}$ ) completely 
from the dried samples, $1 \mathrm{~mL}$ of concentrated hydrofluoric acid (HF, 38\%) and $0.5 \mathrm{~mL}$ of concentrated $\mathrm{HNO}_{3}$ were added and dried. Then, 1 to $2 \mathrm{~mL}$ of $2 \% \mathrm{HNO}_{3}$ and 2 drops of concentrated HF were added to the dried sample until completely dissolved. These sample solutions were diluted with $2 \% \mathrm{HNO}_{3}$ for inductively coupled plasma mass spectrometry (ICP-MS) analysis.

For $\mathrm{Sr}$ isotope analysis with quantitative analysis of REEs, approximately $40 \mathrm{mg}$ of each sample was digested by HF and perchloric acid $\left(\mathrm{HClO}_{4}\right)$ in an open PTFE beaker on a hotplate at a temperature of approximately $140^{\circ} \mathrm{C}$ for $72 \mathrm{~h}$ at NU. After drying the digested solution, it was dissolved in $6 \mathrm{M} \mathrm{HCl}$. White precipitates appeared in $6 \mathrm{M} \mathrm{HCl}$, although the samples were once dissolved during HF digestion. The supernatants (dissolved parts) were separated and divided into two portions for ${ }^{87} \mathrm{Sr} /{ }^{86} \mathrm{Sr}$ analysis and quantitative analysis of REEs. Both portions were dried again. The isotope fraction was dried and then dissolved in $3 \mathrm{~mL}$ of $2.4 \mathrm{M} \mathrm{HCl}$ and loaded on a cation exchange column (BioRad AG50W-X8, 200-400 mesh) with $\mathrm{HCl}$ eluent to isolate Sr. The REE fraction was dissolved in $2 \% \mathrm{HNO}_{3}$ solution. The REE quantitative analysis data were compared with those obtained for the KF-fused samples for a cross-check.

Beryllium and trace elements were quantified by ICP-MS (Agilent 7700x) at NU. Since the KF-fused sample solution had high matrix element concentrations, isobaric interferences and blanks of alkaline earth elements were carefully checked for ICP-MS analysis. The internal standard of indium (In) was used to reduce the effect of ionization efficiencies for the high-matrix sample solution. The helium (He) collision mode and nogas mode were both used to check the isobaric interferences by molecular ions, including $\mathrm{K}^{+}$and $\mathrm{F}^{-}$. In addition, to check the accuracy of the trace element concentrations in the high-matrix sample solutions, two sample solutions with different dilution ratios were prepared and cross-checked. The blanks of some elements, such as $\mathrm{Rb}$, were high (10 $\mu \mathrm{g}$, Table 1) because of the impurities in the KF reagent. All data were corrected for blanks. Analytical errors for each element by ICP-MS were less than $10 \%$.

Approximately $150 \mathrm{ng}$ of the $\mathrm{Sr}$ fraction with $1 \mu \mathrm{L}$ of $2 \mathrm{M} \mathrm{H}_{3} \mathrm{PO}_{4}$ was loaded onto a Ta filament, and the isotope ratio of $\mathrm{Sr}$ was measured by VG Sector $54-30$ thermal ionization mass spectrometry (TIMS) at NU. ${ }^{87} \mathrm{Sr} /{ }^{86} \mathrm{Sr}$ ratios were normalized to ${ }^{86} \mathrm{Sr} /{ }^{88} \mathrm{Sr}=0.1194$. NIST SRM 987 was used as the Sr isotope standard, and repeated analysis of the standard during the sample measurement yielded $0.710240 \pm 0.000010$ ( $1 \mathrm{SD}, n=17$ ).

\section{Results}

\subsection{Beryl Chemistry}

The major oxide and trace element contents of the beryl grains are listed in Table 1. The beryl samples have high $\mathrm{SiO}_{2}$ contents from 65.9 to $67.2 \mathrm{wt} . \%$ and $\mathrm{Al}_{2} \mathrm{O}_{3}$ contents from 18.7 to 19.3 wt.\%. $\mathrm{BeO}$ concentration varies from 10.0 to $11.9 \mathrm{wt} . \%$. The contents of $\mathrm{Na}_{2} \mathrm{O}$ (0.24-0.41 wt.\%), $\mathrm{K}_{2} \mathrm{O}(0.052-0.217$ wt. $\%)$, and $\mathrm{CaO}(0.068-0.087 \mathrm{wt} . \%)$ are very low. $\mathrm{MgO}$ content ranges from 0.007 to $0.023 \mathrm{wt}$. \%, $\mathrm{MnO}$ from 0.004 to $0.008 \mathrm{wt} . \%$, and $\mathrm{Fe}_{2} \mathrm{O}_{3}$ from 0.31 to $1.32 \mathrm{wt} . \%$. Li and Cs concentrations vary from 143 to $179 \mathrm{ppm}$ and from 106 to $260 \mathrm{ppm}$, respectively, and are low. The Rb concentration varies from 14.8 to $84.7 \mathrm{ppm}$ and is not high. The contents of V (0.58-1.29 ppm), Zn (31.9-62.4 ppm), Sr (2.26-3.73 ppm), and $\mathrm{Nb}(0.52-11.8 \mathrm{ppm})$ are low in the beryl samples.

The REE abundances (Table 1 ) are low, and the total REE contents ( $\Sigma$ REEs) range from 1.21 to $5.41 \mathrm{ppm}$ (average $=2.46 \mathrm{ppm}$ ). The total contents of light REEs ( $\Sigma$ LREEs) vary from 0.43 to $4.33 \mathrm{ppm}$ (average $=1.72 \mathrm{ppm}$ ), and the HREE contents range from 0.131 to $0.244 \mathrm{ppm}$ (average $=0.193 \mathrm{ppm}$ ). Yttrium contents range from 0.35 to $0.83 \mathrm{ppm}$ (average $=0.56 \mathrm{ppm})($ Table 1$)$. 
Table 1. Major oxide (wt.\%) and trace element concentrations (ppm) of the beryl grains in the Ebrahim-Attar area.

\begin{tabular}{|c|c|c|c|c|c|c|c|c|}
\hline Sample Name & BYL1 & BYL2 & BYL3 & BYL4 & BYL5 & BYL6 & BYL7 & Blank \\
\hline $\mathrm{SiO}_{2}$ & 66.6 & 66.8 & 66.2 & 67.2 & 65.9 & 66.2 & 67.0 & \\
\hline $\mathrm{Al}_{2} \mathrm{O}_{3}$ & 18.9 & 19.0 & 18.7 & 19.1 & 19.3 & 19.2 & 19.0 & \\
\hline $\mathrm{Fe}_{2} \mathrm{O}_{3}$ & 0.31 & 0.49 & 0.40 & 0.50 & 1.31 & 0.42 & 0.35 & \\
\hline $\mathrm{MnO}$ & 0.005 & 0.006 & 0.006 & 0.004 & 0.008 & 0.005 & 0.005 & \\
\hline $\mathrm{MgO}$ & 0.022 & 0.007 & 0.020 & 0.019 & 0.017 & 0.019 & 0.023 & \\
\hline $\mathrm{CaO}$ & 0.071 & 0.069 & 0.068 & 0.070 & 0.072 & 0.087 & 0.079 & \\
\hline $\mathrm{Na}_{2} \mathrm{O}$ & 0.36 & 0.24 & 0.28 & 0.25 & 0.29 & 0.41 & 0.26 & \\
\hline $\mathrm{K}_{2} \mathrm{O}$ & 0.072 & 0.053 & 0.186 & 0.088 & 0.132 & 0.217 & 0.052 & \\
\hline $\mathrm{P}_{2} \mathrm{O}_{5}$ & 0.009 & 0.007 & 0.007 & 0.006 & 0.008 & 0.013 & 0.007 & \\
\hline $\mathrm{BeO}$ & 11.9 & 11.3 & 10.6 & 10.0 & 10.7 & 10.3 & 10.2 & $<10 \mathrm{ng}$ \\
\hline LOI & 1.61 & 1.63 & 1.63 & 1.65 & 1.69 & 1.70 & 1.68 & \\
\hline Total & 99.9 & 99.7 & 98.1 & 98.9 & 99.4 & 98.5 & 98.6 & \\
\hline $\mathrm{Li}$ & 155 & 143 & 145 & 164 & 173 & 178 & 179 & $40 \mathrm{ng}$ \\
\hline $\mathrm{V}$ & 1.29 & 0.58 & 0.74 & 0.63 & 0.85 & 0.93 & 0.89 & $3 \mathrm{ng}$ \\
\hline $\mathrm{Zn}$ & 55.8 & 40.8 & 33.0 & 52.9 & 31.9 & 62.4 & 51.9 & $70 \mathrm{ng}$ \\
\hline $\mathrm{Rb}$ & 66 & 53 & 55 & 15 & 85 & 72 & 44 & $10 \mu \mathrm{g}$ \\
\hline $\mathrm{Sr}$ & 3.61 & 3.01 & 2.26 & 2.73 & 3.26 & 3.12 & 3.73 & $1 \mathrm{ng}$ \\
\hline $\mathrm{Nb}$ & 0.90 & 11.8 & 6.92 & 0.98 & 2.90 & 2.43 & 0.52 & $2 \mathrm{ng}$ \\
\hline Cs & 199 & 253 & 228 & 106 & 260 & 121 & 167 & $5 \mathrm{ng}$ \\
\hline$Y$ & 0.833 & 0.565 & 0.547 & 0.588 & 0.351 & 0.489 & 0.511 & $90 \mathrm{pg}$ \\
\hline $\mathrm{La}$ & 0.869 & 0.274 & 0.098 & 0.039 & 0.174 & 0.566 & 0.145 & $60 \mathrm{pg}$ \\
\hline $\mathrm{Ce}$ & 2.05 & 0.778 & 0.269 & 0.136 & 0.532 & 1.219 & 0.444 & $140 \mathrm{pg}$ \\
\hline $\operatorname{Pr}$ & 0.224 & 0.087 & 0.035 & 0.014 & 0.047 & 0.131 & 0.038 & $30 \mathrm{pg}$ \\
\hline $\mathrm{Nd}$ & 0.661 & 0.280 & 0.132 & 0.057 & 0.153 & 0.387 & 0.134 & $50 \mathrm{pg}$ \\
\hline $\mathrm{Sm}$ & 0.307 & 0.184 & 0.131 & 0.067 & 0.095 & 0.176 & 0.087 & $11 \mathrm{pg}$ \\
\hline $\mathrm{Eu}$ & 0.0026 & 0.0018 & 0.0009 & 0.0007 & 0.0007 & 0.0017 & 0.0022 & $<5 \mathrm{pg}$ \\
\hline $\mathrm{Gd}$ & 0.220 & 0.164 & 0.154 & 0.113 & 0.094 & 0.141 & 0.105 & $6 \mathrm{pg}$ \\
\hline $\mathrm{Tb}$ & 0.045 & 0.037 & 0.037 & 0.031 & 0.021 & 0.029 & 0.027 & $2 \mathrm{pg}$ \\
\hline Dy & 0.144 & 0.120 & 0.129 & 0.113 & 0.076 & 0.097 & 0.104 & $6 \mathrm{pg}$ \\
\hline Ho & 0.0122 & 0.0112 & 0.0114 & 0.0110 & 0.0064 & 0.0082 & 0.0097 & $5 \mathrm{pg}$ \\
\hline Er & 0.020 & 0.020 & 0.019 & 0.018 & 0.012 & 0.017 & 0.015 & $14 \mathrm{pg}$ \\
\hline $\mathrm{Tm}$ & 0.0023 & 0.0027 & 0.0027 & 0.0027 & 0.0014 & 0.0023 & 0.0028 & $5 \mathrm{pg}$ \\
\hline $\mathrm{Yb}$ & 0.018 & 0.021 & 0.016 & 0.018 & 0.013 & 0.014 & 0.017 & $15 \mathrm{pg}$ \\
\hline $\mathrm{Lu}$ & 0.0023 & 0.0027 & 0.0021 & 0.0019 & 0.0017 & 0.0022 & 0.0028 & $3 \mathrm{pg}$ \\
\hline$\Sigma$ REE & 5.41 & 2.55 & 1.58 & 1.21 & 1.58 & 3.28 & 1.64 & \\
\hline$\Sigma$ LREE & 4.33 & 1.77 & 0.82 & 0.43 & 1.10 & 2.62 & 0.96 & \\
\hline$\Sigma$ HREE & 0.244 & 0.213 & 0.217 & 0.195 & 0.131 & 0.170 & 0.178 & \\
\hline$\Sigma$ HREE $/ \Sigma$ LREE & 0.056 & 0.121 & 0.264 & 0.458 & 0.119 & 0.065 & 0.187 & \\
\hline$(\mathrm{Ce} / \mathrm{La})_{\mathrm{N}}$ & 0.913 & 1.10 & 1.06 & 1.34 & 1.19 & 0.835 & 1.18 & \\
\hline$(\mathrm{La} / \mathrm{Yb})_{\mathrm{N}}$ & 34.8 & 9.59 & 4.33 & 1.57 & 9.96 & 28.0 & 6.14 & \\
\hline$(\mathrm{La} / \mathrm{Sm})_{\mathrm{N}}$ & 1.83 & 0.963 & 0.484 & 0.381 & 1.18 & 2.078 & 1.08 & \\
\hline $\mathrm{Eu} / \mathrm{Eu}^{*}$ & 0.030 & 0.031 & 0.019 & 0.025 & 0.021 & 0.032 & 0.072 & \\
\hline
\end{tabular}

$\mathrm{N}$ denotes chondrite normalization based on Sun and McDonough [44]. Eu/Eu* $=\mathrm{Eu}_{N} / \sqrt{S m_{N} * G d_{N}}, \mu \mathrm{g}=$ microgram, ng $=$ nanogram, and $\mathrm{pg}=$ picogram.

The REE concentrations normalized by chondrite values [44] show flat LREE trends and strong depletions in HREEs, especially in $\mathrm{Tb}-\mathrm{Lu}$, and all of the patterns are similar to each other (Figure 5). All samples strongly show negative Eu anomalies $\left(\mathrm{Eu} / \mathrm{Eu}^{*}=0.019-0.072\right.$, average $=0.033$ ). The REE patterns of beryl grains are more fractionated than those of the host granitic pegmatite. The $\Sigma$ REE values of beryl grains are lower than those of the host pegmatite (3.88-30.3 ppm; [30]). In the host pegmatite, REE patterns are different from those of the beryl grains. The host pegmatites show slightly HREE-enriched patterns, although the beryl grains show HREE-depleted patterns. Meanwhile, both the beryl grains and their host rocks have negative Eu anomalies, which are clearly related to feldspar fractionation [45]. 


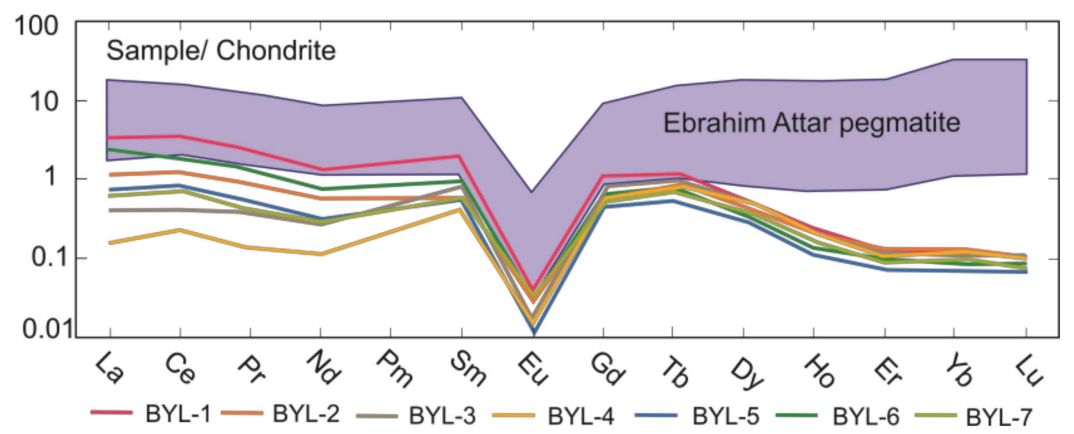

Figure 5. Chondrite-normalized rare earth element (REE) patterns of the Ebrahim-Attar beryl samples based on Sun and McDonough [44]. Data for the Ebrahim-Attar pegmatite are from Azizi et al. [30].

\subsection{Crytallochemistry of Beryl}

The general formula of beryl is well documented by Bragg and West (1926) [46]. Beryl involves rings with $6 \mathrm{Si}-\mathrm{O}$ tetrahedra $\left({ }^{T 1}\right)$, which are associated with Be-O tetrahedra $\left({ }^{\mathrm{T2}}\right)$ at both vertical and lateral positions. Al-O is situated in an octahedral $\left({ }^{O}\right)$ site and is linked to six rings of Si-O tetrahedral position. The center of Si rings involves channels $\left({ }^{\mathrm{ch}}\right)$ that prefer to place alkali elements such as $\mathrm{Na}^{+}, \mathrm{Cs}^{+}$, and $\mathrm{K}^{+}$and water $[9,47] . \mathrm{Al}$ in the ${ }^{O}$ site can be substituted by $\mathrm{Fe}^{3+}, \mathrm{Cr}, \mathrm{V}$, and $\mathrm{Fe}^{2+}$ according to Equations (1) and (2):

$$
\begin{gathered}
{ }^{O} \mathrm{Al} \rightarrow{ }^{O} \mathrm{R}^{3}+{ }^{C} \square \\
{ }^{O} \mathrm{Al} \rightarrow{ }^{O} \mathrm{R}^{2+}+{ }^{O} \mathrm{~A}^{1+}
\end{gathered}
$$

where ${ }^{O} \mathrm{~A}^{1+}$ is an alkali such as $\mathrm{Na}^{+}, \mathrm{Cs}^{+}$, and $\mathrm{K}^{+},{ }^{O}$ and ${ }^{C}$ denote the site of substitution, ions of comparable size are shown as $\mathrm{R}^{2+}$ and $\mathrm{R}^{3+}$, and charge balance is achieved by incorporation of alkalis in the channels.

Belov [48] suggested the substitution of $\mathrm{Li}^{+}$for $\mathrm{Be}^{2+}$. Aurisicchio et al. [47] re-evaluated the geochemistry of beryl based on a negative correlation between Be and Li and defined the mechanism of substitution as follows:

$$
{ }^{\mathrm{T} 2} \mathrm{Li}+{ }^{\mathrm{C}} \mathrm{A} 1^{+} \rightarrow{ }^{\mathrm{T} 2} \mathrm{Be}+{ }^{\mathrm{C}} \square
$$

where ${ }^{\mathrm{C}} \mathrm{A} 1^{+}$is alkalis, and superscripts ${ }^{\mathrm{T} 2}$ and ${ }^{\mathrm{C}}$ denote the site of replacement.

The beryl samples from the Ebrahim-Attar area show a negative correlation between $\mathrm{Be}$ and $\mathrm{Li}$, supporting the substitution of $\mathrm{Li}$ at the tetrahedral position $\left({ }^{\mathrm{T}}\right)$ (Figure 6a). Furthermore, a weak positive correlation between $\mathrm{Fe}+\mathrm{Mg}$ and $\mathrm{Al}$ is evidence of minor substitution to the absence of substitution of $\mathrm{Fe}+\mathrm{Mg}$ at the octahedral site (Figure $6 \mathrm{~b}$ ).
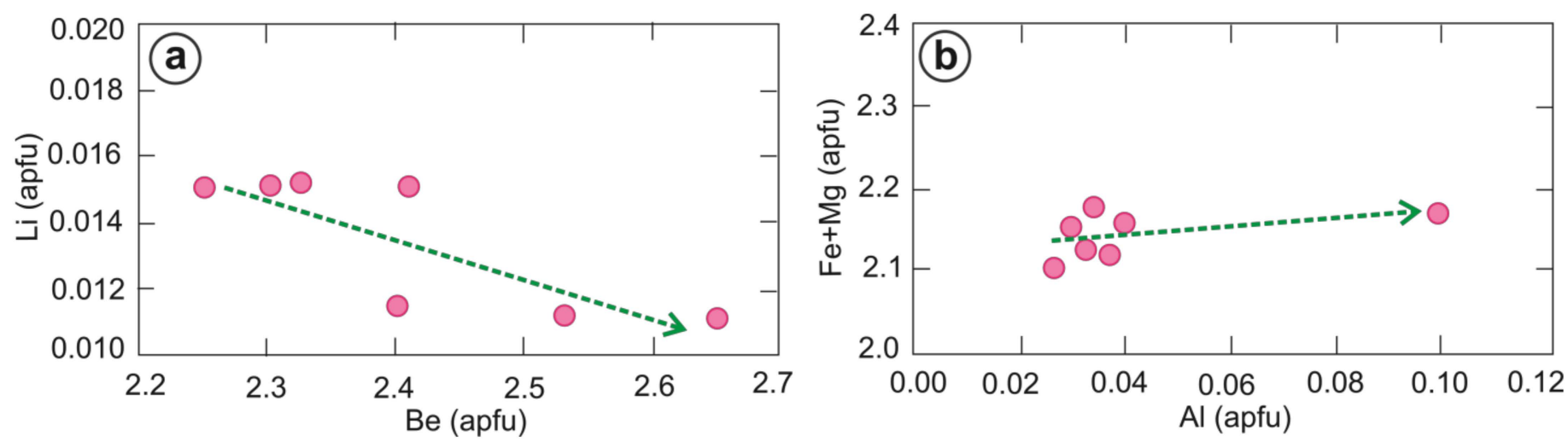

Figure 6. (a) Li vs. Be diagram for the Ebrahim-Attar beryl samples, showing a negative correlation, which supports that $\mathrm{Li}$ is substituted with Be. (b) Fe $+\mathrm{Mg}$ vs. Al diagram, showing a weak positive correlation, which supports the minor substitution of $\mathrm{Fe}+\mathrm{Mg}$ at the octahedral site. $\mathrm{Li}, \mathrm{Be}, \mathrm{Fe}, \mathrm{Mg}$, and $\mathrm{Al}$ (apfu) are calculated based on 18 oxygen atoms. 
According to the chemical composition of Ebrahim-Attar beryls, the apfu of the main component was calculated based on 18 oxygen atoms (Table 2). Thus, the chemical formula is calculated based on 18 oxygen atoms, and the average value of the main component of Ebrahim-Attar beryls is:

$$
{ }^{c h}\left(\mathrm{Na}_{0.054}, \mathrm{~K}_{0.014}, \mathrm{Cs}_{0.001}\right)^{T 2}\left(\mathrm{Be}_{2.412}, \mathrm{Li}_{0.013}\right)_{2.412}{ }^{\mathrm{O}}\left(\mathrm{Al}_{2.145}, \mathrm{Fe}_{0.04}, \mathrm{Mn}_{0.0004}, \mathrm{Mg}_{0.003}\right)_{2.188}{ }^{T 1} \mathrm{Si}_{6.372} \mathrm{O}_{18}
$$

Table 2. Chemical compositions (apfu) based on 18 oxygen atoms in the Ebrahim-Attar beryl.

\begin{tabular}{ccccccccc}
\hline Sample Name & BYL1 & BYL2 & BYL3 & BYL4 & BYL5 & BYL6 & BYL7 & Average \\
\hline $\mathrm{Si}$ & 6.292 & 6.337 & 6.396 & 6.449 & 6.307 & 6.387 & 6.435 & 6.372 \\
$\mathrm{Al}$ & 2.103 & 2.122 & 2.128 & 2.157 & 2.174 & 2.179 & 2.154 & 2.145 \\
$\mathrm{Fe}$ & 0.023 & 0.035 & 0.029 & 0.037 & 0.096 & 0.031 & 0.026 & 0.040 \\
$\mathrm{Mn}$ & 0.0004 & 0.0005 & 0.0005 & 0.0003 & 0.0007 & 0.0004 & 0.0004 & 0.000 \\
$\mathrm{Mg}$ & 0.003 & 0.001 & 0.003 & 0.003 & 0.002 & 0.003 & 0.003 & 0.003 \\
$\mathrm{Ca}$ & 0.0071 & 0.0069 & 0.0070 & 0.0071 & 0.0073 & 0.0089 & 0.0080 & 0.007 \\
$\mathrm{Na}$ & 0.064 & 0.043 & 0.051 & 0.044 & 0.053 & 0.075 & 0.046 & 0.054 \\
$\mathrm{~K}$ & 0.0084 & 0.0062 & 0.0222 & 0.0104 & 0.0156 & 0.0259 & 0.0062 & 0.014 \\
$\mathrm{Be}$ & 2.651 & 2.531 & 2.403 & 2.253 & 2.411 & 2.328 & 2.303 & 2.411 \\
$\mathrm{Li}$ & 0.011 & 0.011 & 0.011 & 0.015 & 0.015 & 0.015 & 0.015 & 0.013 \\
$\mathrm{Cs}$ & 0.0008 & 0.0012 & 0.0008 & 0.0004 & 0.0012 & 0.0004 & 0.0008 & 0.001 \\
$\mathrm{Na} / \mathrm{Li}$ & 5.75 & 3.84 & 4.51 & 2.94 & 3.49 & 4.93 & 3.04 & 4.07 \\
\hline
\end{tabular}

The abovementioned replacement in beryl causes the colored crystal. Hence, the presence of $\mathrm{Fe}^{2+}$ causes a green color in the Ebrahim-Attar beryls.

\section{3. ${ }^{87} \mathrm{Sr}{ }^{\beta 6} \mathrm{Sr}$ Isotope Ratios in the Beryl Grains}

The ${ }^{87} \mathrm{Sr} /{ }^{86} \mathrm{Sr}$ ratios of the seven beryl samples are listed in Table 3. The ${ }^{87} \mathrm{Sr} /{ }^{86} \mathrm{Sr}$ ratios show a wide range from 0.7381 to 0.7734 with an average of $0.7642(n=6)$, except for sample BRYL3, which has an extremely high value $\left({ }^{87} \mathrm{Sr} /{ }^{86} \mathrm{Sr}=0.8060\right)$, and the separated beryl grains do not have a homogenous composition. Alkali elements such $\mathrm{K}, \mathrm{Rb}$, and $\mathrm{Cs}$ could occupy a large space in a silicon tetrahedral ring in the beryl structure, and charge balance generally occurs by substitution of $\mathrm{Al}^{3+}$ in $\mathrm{Si}^{4+}$. More than $90 \%$ of various types of beryl have high concentrations of $\mathrm{Rb}$ (5-50 ppm) and low Sr (usually less than $1 \mathrm{ppm}$ ), resulting in a high ${ }^{87} \mathrm{Rb} /{ }^{86} \mathrm{Sr}$ ratio in beryl [49]. Based on the concentrations of $\mathrm{Rb}$ and $\mathrm{Sr}$ in beryl, ${ }^{87} \mathrm{Rb} /{ }^{86} \mathrm{Sr}$ ratios were calculated for the seven samples (Table 3). The ${ }^{87} \mathrm{Sr} /{ }^{86} \mathrm{Sr}$ vs. ${ }^{87} \mathrm{Rb} /{ }^{86} \mathrm{Sr}$ diagram for the six beryl samples, except BRYL3, shows a weak, positive trend. The ${ }^{87} \mathrm{Sr} /{ }^{86} \mathrm{Sr}_{(\mathrm{i})}$ ratio, $0.739 \pm 0.036$ (Figure 7), was calculated based on ISOPLOT software version 4.15 .

Table 3. $\mathrm{Rb}-\mathrm{Sr}$ abundances and $\mathrm{Sr}$ isotope ratios of the beryl grains.

\begin{tabular}{cccccccc}
\hline Sample Name & BRYL1 & BRYL2 & BRYL3 & BRYL4 & BRYL5 & BRYL6 & BRYL7 \\
\hline${ }^{87} \mathrm{Sr} /{ }^{86} \mathrm{Sr}$ & 0.749177 & 0.768480 & 0.806010 & 0.752527 & 0.762224 & 0.773416 & 0.738121 \\
Error (1SE) & 0.000007 & 0.000016 & 0.000006 & 0.000008 & 0.000007 & 0.000006 & 0.000007 \\
$\mathrm{Rb}(\mathrm{ppm})$ & 66 & 53 & 55 & 15 & 85 & 72 & 44 \\
$\mathrm{Sr}(\mathrm{ppm})$ & 3.61 & 3.01 & 2.26 & 2.73 & 3.26 & 3.12 & 3.73 \\
${ }^{87} \mathrm{Rb} /{ }^{86} \mathrm{Sr}$ & 53 & 52 & 71 & 16 & 76 & 67 & 34 \\
\hline
\end{tabular}




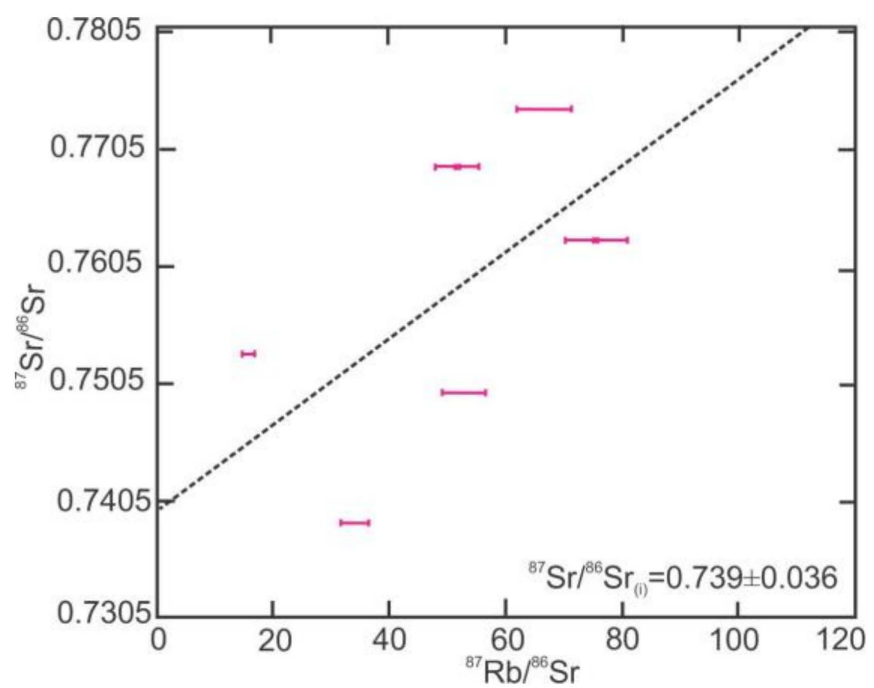

Figure 7. ${ }^{87} \mathrm{Sr} /{ }^{86} \mathrm{Sr}$ vs. ${ }^{87} \mathrm{Rb} /{ }^{86} \mathrm{Sr}$ diagram. The Ebrahim-Attar beryl sample plots show an intercept of ${ }^{87} \mathrm{Sr} /{ }^{86} \mathrm{Sr}_{(\mathrm{i})}=0.739 \pm 0.036$. The external error for ${ }^{87} \mathrm{Sr} /{ }^{86} \mathrm{Sr}$ ranges from 0.000012 to 0.000019 , which is calculated based on 1SE and 1SD of the standard error (NIST-SRM 987).

\section{Discussion}

\subsection{Beryl and Its Parental Magma}

The chemical composition of beryl grains is associated with the geochemical features of their host rocks [50,51]. Barton and Young [4] compared the composition of various Be-bearing host rocks based on the alkali, silica, and alumina components on total-alkali $\left(\mathrm{Na}_{2} \mathrm{O}+\mathrm{K}_{2} \mathrm{O}\right)$ vs. silica $\left(\mathrm{SiO}_{2}\right)$ and $\mathrm{CaO} /\left(\mathrm{Na}_{2} \mathrm{O}+\mathrm{K}_{2} \mathrm{O}+\mathrm{CaO}\right)$ vs. $\mathrm{Al}_{2} \mathrm{O}_{3} /\left(\mathrm{Na}_{2} \mathrm{O}+\mathrm{K}_{2} \mathrm{O}\right.$ $+\mathrm{CaO}$ ) diagrams (Figure 8). On the $\mathrm{Na}_{2} \mathrm{O}+\mathrm{K}_{2} \mathrm{O}$ vs. $\mathrm{SiO}_{2}$ diagram, the Ebrahim-Attar whole-rock samples plot on the lithium-cesium-tantalum type with subalkaline affinity (Figure 8a). Barton and Young [4] subdivided igneous Be-bearing rocks into four groups based on contents of $\mathrm{Al}_{2} \mathrm{O}_{3}$ and $\mathrm{SiO}_{2}$ : (1) strongly to weakly peraluminous with $\mathrm{BeO}$ $\mathrm{Al}_{2} \mathrm{O}_{3}-\mathrm{SiO}_{2}-\mathrm{H}_{2} \mathrm{O}$ (BASH) family group; (2) metaluminous to weakly peraluminous with phenakite and bertrandite; (3) peralkaline to metalumionus quartz-saturated and enriched in $\mathrm{Nb}-\mathrm{Y}-\mathrm{F}$; (4) peralkaline (quartz undersaturated), which has a high content of $\mathrm{Nb}-\mathrm{REE}-\mathrm{Y}$ with Ca-Na-Be silicate.

Based on $\mathrm{CaO} /\left(\mathrm{Na}_{2} \mathrm{O}+\mathrm{K}_{2} \mathrm{O}+\mathrm{CaO}\right)$ vs. $\mathrm{Al}_{2} \mathrm{O}_{3} /\left(\mathrm{Na}_{2} \mathrm{O}+\mathrm{K}_{2} \mathrm{O}+\mathrm{CaO}\right)$ variation, the Ebrahim-Attar granitic pegmatite shows a strongly peraluminous signature (Figure $8 \mathrm{~b}$ ). The Ebrahim-Attar pegmatite has a high content of $\mathrm{SiO}_{2}(71.4-81.0 \mathrm{wt}$ \%) and low content of $\mathrm{Fe}_{2} \mathrm{O}_{3}(0.19-0.69$ wt.\%), $\mathrm{MgO}(0.04-0.12$ wt.\%), and $\mathrm{CaO}(0.33-1.73$ wt.\%), which are similar to peraluminous fertile granite [52]. The Ebrahim-Attar pegmatites have low contents of $\Sigma$ REEs (3.88-30.3 ppm). Mostly, the $\Sigma$ REE abundances in fertile granites vary from 1 to 20 times higher than those of chondrite [52] and are similar to those of the Ebrahim-Attar pegmatites (Figure 5). The Ebrahim-Attar granite contains green muscovite and tourmaline with coarse-grained graphic texture, which is a common feature in fertile granite $[43,53]$. 

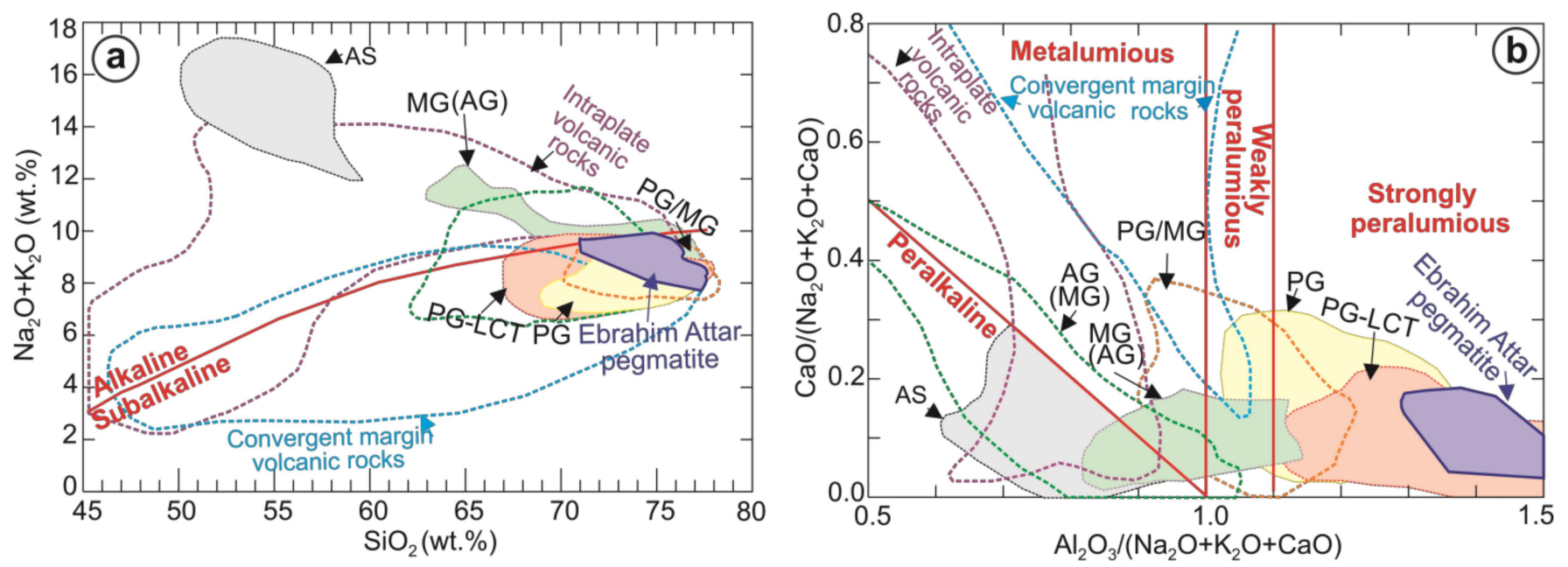

Figure 8. (a) Total alkali vs. silica plot with fields of selected whole-rock chemical data of Be deposits [4]. The compositional division of alkaline and subalkaline is from Wilson [54]. The Ebrahim-Attar granitic pegmatites plot in the LCT-type field. (b) $\mathrm{CaO} /\left(\mathrm{Na}_{2} \mathrm{O}+\mathrm{K}_{2} \mathrm{O}+\mathrm{CaO}\right)$ vs. $\mathrm{Al}_{2} \mathrm{O}_{3} /\left(\mathrm{Na}_{2} \mathrm{O}+\mathrm{K}_{2} \mathrm{O}+\mathrm{CaO}\right)$ plot (wt. $\%$ ) with the projection of composite Be deposit data [4]. The Ebrahim-Attar granitic pegmatites show a strongly peraluminous signature. Data for the Ebrahim-Attar granitic pegmatites are from Azizi et al. [30]. PG-LCT = LCT-type; PG = strongly peraluminous; PG/MG = peraluminous granite; $\mathrm{MG}(\mathrm{AG})=$ metaluminous granite; $\mathrm{AG}(\mathrm{MG})=$ peralkaline; $(\mathrm{AG})$ = peralkaline syenites.

Fertile granite is defined as the parental granite of more evolved rare-metal pegmatite dikes [43]. The granitic pegmatite is related to LCT pegmatite, which has high contents of $\mathrm{Li}, \mathrm{Cs}, \mathrm{Ta}, \mathrm{Nb}, \mathrm{Rb}, \mathrm{B}$, and Sn [16,43,55]. Černý et al. [56] reported that in a fertilized system, lithophile REEs increase gradually during the progress of crystal fractionation from granite to pegmatite. Rare alkali elements such as $\mathrm{Rb}$ and Cs, high-field-strength elements (HFSE) such as $\mathrm{Nb}$ and $\mathrm{Ta}$, and some ratios such as $\mathrm{Rb} / \mathrm{Sr}, \mathrm{Nb} / \mathrm{Ta}$, and $\mathrm{Zr} / \mathrm{Hf}$ are key indicators of granite fractionation [57].

The Ebrahim-Attar granitic pegmatites have high ratios of $\mathrm{Nb} / \mathrm{Ta}$ (4.79-16.3) and $\mathrm{Zr} / \mathrm{Hf}$ (12.2-19.1) compared with the highly evolved Altay system [58] with $\mathrm{Nb} / \mathrm{Ta}<5$ and $\mathrm{Zr} / \mathrm{Hf}<10$ [58]. Highly evolved granite is distributed with low $\mathrm{Nb} / \mathrm{Ta}$ and $\mathrm{Zr} / \mathrm{Hf}$ ratios [59]. The $\mathrm{K} / \mathrm{Rb}$ ratio in the more fractionated leucogranite is less than 50 [59] and varies from 69.6 to 194 in the Ebrahim-Attar granitic pegmatites. This is consistent with less-evolved pegmatite. The most evolved pegmatite is located in the distal position to the parental granite, and the less-evolved pegmatite is in the proximal position. Therefore, the distance of parental magma could control the degree of evolution [60]. Considering these geochemical features, the Ebrahim-Attar granitic pegmatite can be classified as a less evolved, proximal pegmatite.

Herein, we compare the Ebrahim-Attar granitic pegmatite with Be-bearing LCT pegmatites, such as Zealand station dikes, pegmatitic-aplite beryl-rich dikes, and New Brunswick, Canada [57]. The Ebrahim-Attar pegmatite has almost the same contents of $\mathrm{Rb}, \mathrm{Nb}, \mathrm{Cs}$, and $\mathrm{Ta}$ and the same ratios of $\mathrm{Nb} / \mathrm{Ta}, \mathrm{Zr} / \mathrm{Hf}$, and $\mathrm{Rb} / \mathrm{Sr}$ as the Zealand station dikes (Table 4).

Azizi et al. [30] clarified that the Ebrahim-Attar pegmatite is syn- to postcollisional, which is consistent with most LCT pegmatites [7]. The estimated temperature based on the zircon saturation index [61] ranges from 586 to $755^{\circ} \mathrm{C}$ (average $=629{ }^{\circ} \mathrm{C}$ ) and is low. Generally, peraluminous granite originates at approximately $750-800{ }^{\circ} \mathrm{C}$ by melting feldspar, quartz, and muscovite in a eutectite system [62]. Be-bearing pegmatite would be saturated with Be at temperatures below $600{ }^{\circ} \mathrm{C}$ [43]; therefore, the Ebrahim-Attar pegmatite favors beryl crystallization. The crystallization pressure of Ebrahim-Attar granitic pegmatite is estimated by the quartz-geobarometer in peraluminous rock based on Yang et al. [63]. For calculating pressure, $\mathrm{Fe}^{+3} \#$ (molar ferric-ferrous iron oxide ratio) is defined by applying Equation (4) [63]. 
Table 4. Comparison of chemical compositions of the Ebrahim-Attar granitic pegmatite [30] and Zealand station dyke as Be-bearing LCT in Canada [57].

\begin{tabular}{ccc}
\hline Name & $\begin{array}{c}\text { Ebrahim-Attar Granitic } \\
\text { Pegmatite }\end{array}$ & Zealand Station Dyke \\
\hline $\mathrm{Rb}$ & $145-440$ & $218-327$ \\
$\mathrm{Cs}$ & $0.6-4.7$ & $6-22$ \\
$\mathrm{Nb}$ & $9.3-71.4$ & $12.0-21.3$ \\
$\mathrm{Ta}$ & $0.57-9.14$ & $3-14$ \\
$\mathrm{Rb} / \mathrm{Sr}$ & $4.5-60$ & $4.1-15.8$ \\
$\mathrm{Nb} / \mathrm{Ta}$ & $4.8-16.3$ & $2.6-7.1$ \\
$\mathrm{Zr} / \mathrm{Hf}$ & $12.2-19.1$ & $12.6-76.9$ \\
\hline
\end{tabular}

$$
\mathrm{Fe}^{+3} \#=\mathrm{Fe}_{2} \mathrm{O}_{3} /\left(\mathrm{FeO}+\mathrm{Fe}_{2} \mathrm{O}_{3}\right)
$$

Therefore, the crystallization pressure of Ebrahim-Attar granitic pegmatite ranges from $233-246 \mathrm{MPa}$ at a depth near $8.0-9.5 \mathrm{~km}$.

\subsection{Geochemical Characteristics of Beryl Grains}

Beryllium is a highly incompatible element with low contents in the crust and mantle [64]. Due to the low content of Be in the Earth, the generation of beryl requires a very high Be concentration during magmatic differentiation and/or hydrothermal processes [65]. More than $75 \%$ of fractional crystallization needs to concentrate sufficient Be in magma to produce beryl. Alkali elements such as $\mathrm{Li}, \mathrm{Na}, \mathrm{K}$, and $\mathrm{Cs}$ are major impurities in beryl and are valuable for determining magmatic differentiation or hydrothermal processes in the beryl. Hydrothermal beryl is distinguished by a high content of total alkalis (approximately $14 \mathrm{wt} . \%$ ), and igneous beryl shows total alkali contents up to 7 wt.\% [66-68]. Beus [66] classified beryl into four types: (1) alkali-free beryl (total $\mathrm{R}_{2} \mathrm{O}<0.5 \%$, where $\mathrm{R}=\mathrm{Na}, \mathrm{Li}, \mathrm{Cs}, \mathrm{K}$ ); (2) $\mathrm{Na}$ beryl (total $\mathrm{R}_{2} \mathrm{O}>0.5 \%, \mathrm{Na}_{2} \mathrm{O}=0.5-2 \%$, $\left.\mathrm{LiO}_{2}=0.1-0.5 \%\right)$; (3) Na-Li beryl $\left(\mathrm{Li}_{2} \mathrm{O}=0.5-1.5\right.$ and $\left.\mathrm{Na}_{2} \mathrm{O}=1-2.5 \%\right)$ and (4) Li-Cs beryl $\left(\mathrm{Li}_{2} \mathrm{O}=0.1-1 \%, \mathrm{Cs}_{2} \mathrm{O}<3 \%, \mathrm{Na}_{2} \mathrm{O}=0.3-1 \%\right)$. The Ebrahim-Attar beryl has low alkali contents $\left(\mathrm{Na}_{2} \mathrm{O}+\mathrm{K}_{2} \mathrm{O}+\mathrm{Li}_{2} \mathrm{O}+\mathrm{Cs}_{2} \mathrm{O}=0.35\right.$ to $0.68 \mathrm{wt}$. $\%$, with an average of $0.47 \mathrm{wt} \%$ ), which is associated with the alkali-free beryl type of Beus classification [66]. The alkali-free Ebrahim-Attar beryl directly crystallized from the granitic melt.

It is well documented that early alkali-poor beryl forms prismatic crystals. The prismatic habit appears in the late stage of pegmatite evolution. Additionally, alkali substitution in Be-tetrahedra causes lateral growth [69]. Thus, the transition of a prismatic to a tabular pattern with alkali-rich beryl reflects the hydrothermal process in the late stage of pegmatite evolution $[69,70]$. The accommodation of alkali elements such as $\mathrm{Li}, \mathrm{Na}, \mathrm{K}$, $\mathrm{Rb}$, and $\mathrm{Cs}$ and substitution of $\mathrm{Be}^{2+}$ and $\mathrm{Li}^{+}$in the beryl structure along the c-axis cause the tabular beryl to form [71]. The Ebrahim-Attar beryl has a prismatic euhedral shape and is interpreted as the magmatic source, consistent with the geochemistry of beryl (Figure 4).

With increasing alkali element contents in the Ebrahim-Attar beryls, the BeO value shows a weak decreasing trend (Figure 9), and the alkali element contents probably control the shape and Be concentration [72]. This could explain the high BeO content (10.0 to 11.9 wt.\%) in the alkali-poor beryl in the Ebrahim-Attar granite.

The contents of alkali elements ( $\mathrm{Na}, \mathrm{Cs}$, and $\mathrm{Li}$ ) and divalent metals such as Fe and $\mathrm{Mg}$ in beryl are also used to determine the geochemical signatures of host pegmatite $[11,15,18]$. The Cs content of beryl increases during magma evolution (crystallization and differentiation) and is convenient to distinguish primitive (undifferentiated) magma from evolved magma [69,70]. Beryl in evolved pegmatite becomes Cs-dominant [69]. The Cs content is 106-260 ppm in the Ebrahim-Attar pegmatite beryl (Table 1). The evolution of pegmatitic melts can be inferred from the $\mathrm{Na} / \mathrm{Li}$ vs. Cs relationship in beryl grains [9,73]. Trueman and Cerny [73] show a progressive evolution trend in pegmatite based on the variation of $\mathrm{Na} / \mathrm{Li}$ (apfu) and Cs content (wt.\%) in beryl. Figure 10 shows that the Ebrahim-Attar 
beryl samples plot in field A of the magmatic trend from Trueman and Cerny [73], and it is concluded that it is a less-evolved pegmatite.

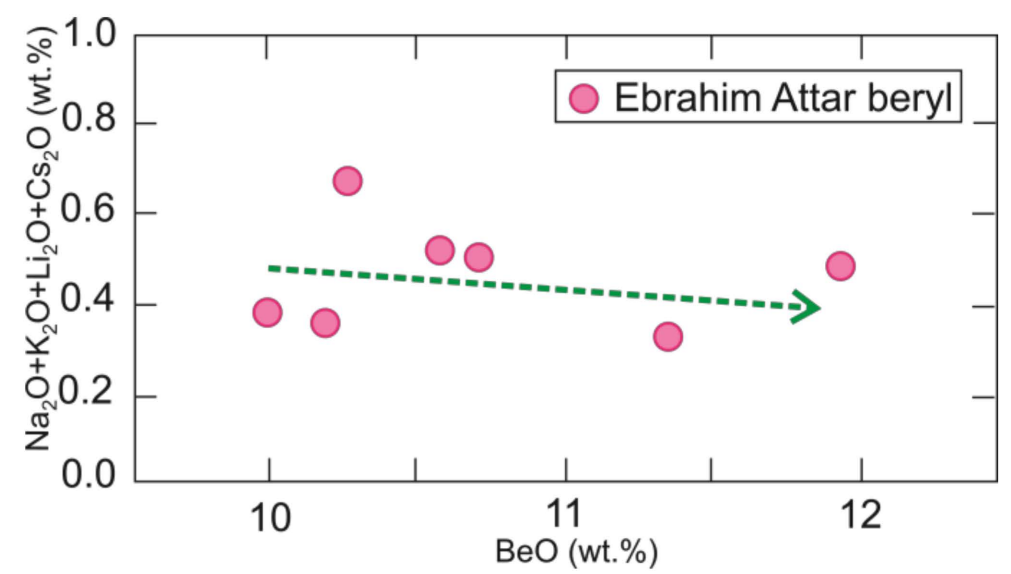

Figure 9. The plot of total alkali element content $\left(\mathrm{Na}_{2} \mathrm{O}+\mathrm{K}_{2} \mathrm{O}+\mathrm{Li}_{2} \mathrm{O}+\mathrm{Cs}_{2} \mathrm{O}\right)$ vs. $\mathrm{BeO}$ of the Ebrahim-Attar beryl shows a weak negative correlation.

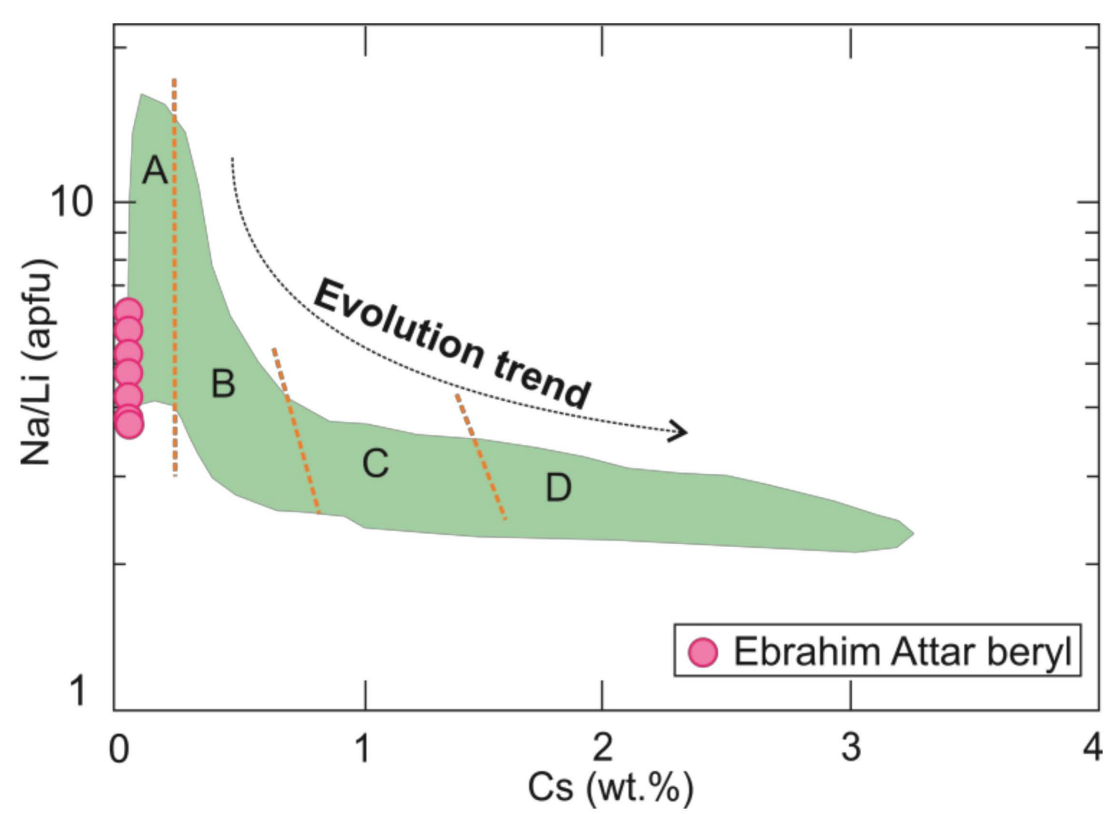

Figure 10. Diagram of Na/Li vs. Cs to compare the geochemical compositions of Ebrahim-Attar beryl with magmatic trend proposed by Trueman and Cerny [73] and divided pegmatite into four groups: (A) barren and geochemically primitive beryl type and less-evolved pegmatite; (B) geochemically evolved beryl-columbite and beryl- columbite-phosphate pegmatite; (C) albite-spodumene and complex pegmatite; (D) highly fractionated Li, Cs, and Ta-rich complex pegmatite. The beryl samples are plotted in less-evolved pegmatite.

The content of $\mathrm{Na}_{2} \mathrm{O}$ in the Ebrahim-Attar beryls varies from 0.24 to 0.41 (wt.\%), and the $\mathrm{FeO}$ content ranges from 0.28 to 1.18 (wt.\%); that is, the Ebrahim-Attar beryls plot in the magmatic field on the $\mathrm{Na}_{2} \mathrm{O}$ vs. $\mathrm{FeO}$ diagram [74] (Figure 11). One sample shows a high content of $\mathrm{FeO}(1.18 \mathrm{wt} . \%)$, which is probably because of fine biotite inclusions in the beryl grain. 


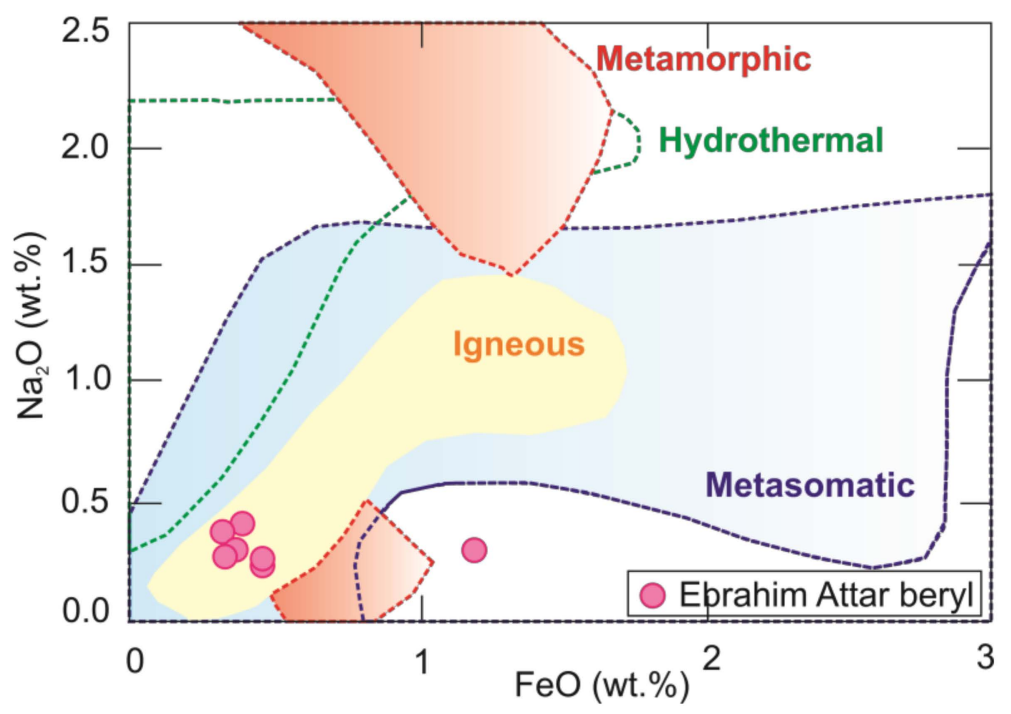

Figure 11. $\mathrm{Na}_{2} \mathrm{O}$ vs. $\mathrm{FeO}$ (wt.\%) diagram. The Ebrahim-Attar beryl samples plot in the magmatic source field. Data for magmatic, hydrothermal, metasomatic, metamorphic, and hydrothermal beryl fields are from Merino et al. [74].

\subsection{Beryl Mineralization}

Four main factors controlling the solubility and saturation of Be in granitic magma are (1) melt composition, (2) fractionation, (3) temperature [12,75], and (4) possible reaction of fluxing elements such as B, P, and F $[75,76]$. The main source for LCT-type pegmatite is S-type granites [77], and the S-type granites have a high value of alumina, a high ratio of $\mathrm{K} /(\mathrm{K}+\mathrm{Na})$, and high contents of $\mathrm{Li}$ and $\mathrm{Cs}$ [77], which are mainly produced from the anatexis of the metapelites rocks [77].

The Ebrahim-Attar granitic pegmatite samples show ${ }^{87} \mathrm{Sr} /{ }^{86} \mathrm{Sr}(\mathrm{i})=0.7081$ and ${ }^{143} \mathrm{Nd} /{ }^{144} \mathrm{Nd}(\mathrm{i})=0.5122$, calculated based on $102 \mathrm{Ma}$ [30]. The Ebrahim-Attar beryl samples show similar ${ }^{87} \mathrm{Sr} /{ }^{86} \mathrm{Sr}(\mathrm{i})=0.739 \pm 0.036$. This feature clarifies a contribution of the older continental crust and/or metasediment [30] and sufficiently supports the source of Be-bearing LCT pegmatite. Clay minerals have a high amount of rare alkali elements [78]. During metamorphism, white and black mica is produced due to the increase in temperature. These minerals provide a large amount of storage for alkali-earth elements, including Be [79]. During partial melting, muscovite breaks down, and some trace elements, such as $\mathrm{Be}$, enter the melt, leading to Be being sufficiently enriched and saturated in the pegmatiteforming magma to produce beryl [62]. The Ebrahim-Attar granitic pegmatite is highly peraluminous with a high content of $\mathrm{SiO}_{2}$. The $\mathrm{BASH}\left(\mathrm{BeO}-\mathrm{Al}_{2} \mathrm{O}_{3}-\mathrm{SiO}_{2}-\mathrm{H}_{2} \mathrm{O}\right)$ mineral assemblage is stable when silica activity is high [4] and controls the diffusion of nonalkali elements [80]. The degree of fractionation is an alternative process that controls the concentration of incompatible elements such as Be in the melt [60]. Crystallization of quartz and feldspar increases the content of Be in the peraluminous granitic melt [74].

Selway et al. [43] suggested schematic complex zonation from parental peraluminous granite to rare-metal granite based on Černý [81] (Figure 12a). The contents of incompatible elements increase with the distance from the source of granitic magma and the degree of fractionation [43]. The solubility of lithophile rare elements increases with increasing fluxing phases such as $\mathrm{F}, \mathrm{B}, \mathrm{Li}$, and $\mathrm{H}_{2} \mathrm{O}$ and decreases with the crystallization temperature of pegmatite [82]. These volatile components cause the melt to migrate far from the source [43], and successively, the incompatible elements can precipitate far from the original melt. Due to the decreasing temperature, the incompatible elemental solubility gradually decreases, and finally, some zonation occurs for these elements [43] (Figure 12). The elemental zonation from the source is as follows: Be pegmatite, Be-Nb-Ta pegmatite, $\mathrm{Li}-\mathrm{Be}-$ $\mathrm{Ta}-\mathrm{Nb}$ pegmatite, and Li-Be-Cs-Ta-Nb pegmatite. Higher contents of incompatible elements are observed in the most distal pegmatite [43] (Figure 12a). 

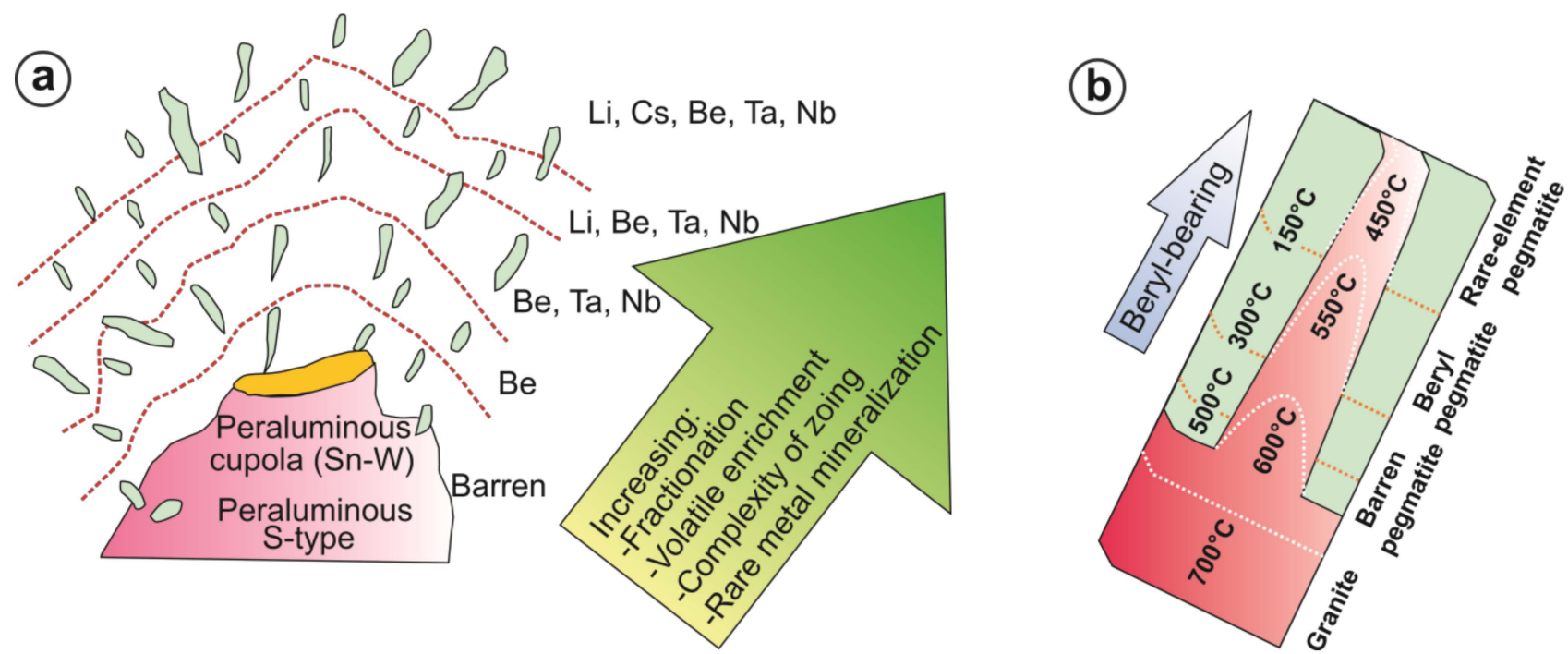

Figure 12. Schematic overview of regional zoning in a cogenetic parent + pegmatite group pegmatite increasing in the degree of evolution with increasing distance from the parent granite. Incompatible elements are more enriched in the most distal pegmatite [12,55]. (a) By increasing the distance from peraluminous S-type magma, the fractionation degree increased, the volatile value could be enriched, the zoning became more complex, and rare metals precipitated in the distal part. (b) During the undercooling of the pegmatite dike, in the proximal part, barren pegmatite formed with the mineral sequence of plagioclase $\left(\mathrm{An}_{10-15}\right)$, muscovite, and $\mathrm{K}$-feldspar, beryl was saturated at approximately $600^{\circ} \mathrm{C}$, and Be-pegmatite was produced. In the distal pegmatite, rare metal mineralization occurred. Modified from Selway et al. [43].

In general, the complexity of zonation and the degree of crystal fractionation in pegmatite increase with distance from the granite source [79]. Unzonation pegmatites are the main sources for feldspar, mica, and quartz deposits [79]. Beryl is the first rare-metal mineral crystallized in the proximal, muscovite-rich LCT pegmatite $[18,73]$. Therefore, based on beryl dominance, Ebrahim-Attar granitic pegmatite could be classified as Bepegmatite, consistent with less-evolved granites.

Based on the model suggested by Selway et al. [43], Sn and W mineralization occurred at the contact of barren rocks with Be-pegmatite (Figure 12a). This is also consistent with tungsten mineralization as a skarn type in the contact of granitic hosts with carbonate rocks and near the Ebrahim-Attar Be-pegmatite [30]. All lines of evidence show that the Ebrahim-Attar pegmatite was generated proximal to the parental granite. According to field observations, beryl occurs as megacrystals at the granite and inner pegmatite border, showing a higher degree of fractionation due to the host granite. Be-bearing pegmatite would be saturated at temperatures below $600{ }^{\circ} \mathrm{C}$ in peraluminous granite [52] (Figure 12b). Overall, the existence of Be over the saturation level and the lower temperature are two essential factors to initiate the growth of beryl [12]. The crystallization temperature in the Ebrahim-Attar granitic pegmatite varies from 586 to $755^{\circ} \mathrm{C}$ with an average of $629^{\circ} \mathrm{C}$ and is lower than that in the inner part of the pegmatite, which is favorable for beryl crystallization. The temperature of the rare element pegmatite is lower (approximately $400-450{ }^{\circ} \mathrm{C}$ ) because the margin of the pegmatite dyke is quickly cooled [77]. London et al. [12] suggested that barren pegmatite occurs near the main silicate melt during the undercooling of silicate dike, with mineral sequences including plagioclase $\left(\mathrm{An}_{10-15}\right)$, muscovite, and $\mathrm{K}$-feldspar (Figure $7 \mathrm{~b}$ ). When the temperature reaches approximately $600^{\circ} \mathrm{C}$, Be must be saturated to form Be-pegmatite (Figure 12b). The temperature for the Ebrahim-Attar pegmatite is consistent with Be-pegmatite on the models for LCT pegmatite of London et al. [12] and Selway et al. [43] (Figure 12). Be has low solubility in the melt because its solubility is related to $\mathrm{Al}_{2} \mathrm{O}_{3}$ activity [16]. The solubility of Be could be increased by the existence of a fluxing component [75]. Fluxing components such as $\mathrm{F}, \mathrm{B}, \mathrm{P}$, and $\mathrm{H}_{2} \mathrm{O}$ in metamorphosed sedimentary rocks lead to peraluminous feathers, which are essential for the genesis of LCT pegmatite [16]. 
Furthermore, ${ }^{87} \mathrm{Sr} /{ }^{86} \mathrm{Sr}(\mathrm{i})(0.7081)$ and ${ }^{143} \mathrm{Nd} /{ }^{144} \mathrm{Nd}(\mathrm{i})$ (0.5122) provide evidence of continental crust origin for the Ebrahim-Attar granitic pegmatite [30]. The peraluminous signature supports metasedimentary and Be sources in the Ebrahim-Attar granitic pegmatite. In the transition of peraluminous host rock to pegmatite, the Be content increases in the melt. In addition, the composition of plagioclase shifts from oligoclase in granite to albite in pegmatite, leading to some Be extraction. The Ebrahim-Attar pegmatite is not well zoned, with a low degree of evolution. These lines of evidence are consistent with proximal pegmatites with low rare metals. The proximal pegmatite contains low Be, indicating that the beryl could be saturated and precipitated in mineral sequences during cooling.

\section{Conclusions}

The highlighted conclusions on the geochemistry of the beryl and its host rock in the Ebrahim-Attar area are as follows:

1. According to the mineral sequence, beryl is the only Be-bearing mineral, and its host rock is classified as Be-pegmatite in the Ebrahim-Attar area.

2. The host rock has an LCT pegmatite and is a less-evolved pegmatite with high values of $\mathrm{Nb} / \mathrm{Ta}$ (4.79-16.3) and $\mathrm{Zr} / \mathrm{Hf}$ (12.2-19.1).

3. Pale-green to white-colored beryl in the host granite appears as euhedral crystals and is alkali-poor beryl with low amounts of $\mathrm{Na}_{2} \mathrm{O}, \mathrm{K}_{2} \mathrm{O}, \mathrm{Li}_{2} \mathrm{O}$, and $\mathrm{Cs}_{2} \mathrm{O}$.

4. Concentrations of $\mathrm{Cs}$ and $\mathrm{Na} / \mathrm{Li}$ values in the beryl grains imply a magmatic signature and suggest a relation to less-evolved granite.

5. High ${ }^{87} \mathrm{Sr} /{ }^{86} \mathrm{Sr}$ ratios of both the beryl and its host granite are consistent with continental crust contributions from their sources.

Author Contributions: Conceptualization, H.A.; Data curation, N.D. and Y.A.; Formal analysis, N.D.; Funding acquisition, M.T.; Investigation, N.D. and H.A.; Methodology, N.D., H.A. and Y.A.; Software, N.D. and Y.O.M.; Writing-review \& editing, H.A., Y.A., M.M., M.T. and Y.O.M. All authors have read and agreed to the published version of the manuscript.

Funding: This research was funded by the Japan Society for Promotion of the Science (JSPS) KAKENHI grant number 17H011671 and the FY2020 International Joint Research Program of the Institute for Space-Earth Environmental Research (ISEE), Nagoya University (Japan), No. 2020-02-003.

Data Availability Statement: All data derived from this research are presented in the enclosed figures and tables.

Acknowledgments: The authors would like to thank B. Mehrabi and S. Mehrabani for fieldwork assistance. We would you like to thanks from both assistant editor Milicev, and Dale Du. Additionally, thoughtful comments by two anonymous reviewers on this manuscript are gratefully acknowledged.

Conflicts of Interest: The authors declare no conflict of interest.

\section{References}

1. Shannon, R.D. Revised Effective Ionic Radii and Systematic Study of Inter Atomic Distances in Halides and Chalcogenides in Halides and Chaleogenides. Acta Crystallogr. 1976, 32, 751-767. [CrossRef]

2. Uher, P.; Bačík, P.; Fridrichová, J. Beryllium silicate minerals in granite-pegmatite suites: Tracers of magmatic to hydrothermal and tectonic evolution (examples from Western Carpathians). Carpathica 2019, 106-107. [CrossRef]

3. Foley, N.K.; Jaskula, B.W.; Piatak, N.M.; Schulte, R.F. Beryllium; Schulz, K.J., DeYoung John, J.H., Jr., Seal, R.R., II, Bradley, D.C., Eds.; U.S. Geological Survey: Reston, VA, USA, 2017.

4. Barton, M.D.; Young, S. Non-pegmatitic Deposits of Beryllium: Mineralogy, Geology, Phase Equilibria and Origin. Rev. Mineral. Geochem. 2002, 50, 591-691. [CrossRef]

5. Sardi, F.E.G. Pegmatitic beryl as indicator of melt evolution: Example from the Velaco district, Pampeana pegmatite province, Argentina and review of worldwide occurrences. Can. Mineral. 2014, 52, 809-836. [CrossRef]

6. Hörmann, P. Beryllium. In Handbook of Geochemistry; Wedepohl, K., Ed.; Springer: Berlin/Heidelberg, Germany, $1978 ;$ p. 458.

7. Bradley, D.; Mccauley, A. A Preliminary Deposit Model for Lithium-Cesium-Tantalum (LCT) Pegmatites; U.S. Geological Survey: Reston, VA, USA, 2016.

8. Foley, N.K.; Hofstra, A.H.; Lindsey, D.A.; Seal, R.R., II; Jaskula, B.W.; Piatak, N.M. Occurrence Model for Volcanogenic Beryllium Deposits; U.S. Geological Survey: Reston, VA, USA, 2012. 
9. Černý, P. Mineralogy of beryllium in granitic pegmatites. Mineral. Geochem. 2002, 50, 405-444. [CrossRef]

10. Prikryl, J.; Novák, M.; Filip, J.; Gadas, P.; Vašinová, M.G. Iron-Bearing Beryl from Granitic Pegmatites; EMPA, LA-ICP-MS, Mössbauer Spectroscopy and Powder XRD Study. In Proceedings of the PEG 2013: The 6th International Symposium on Granitic-Pegmatites, New Orleans, LA, USA, 26 May-2 June 2013; pp. 115-116.

11. Uher, P.; Chudík, P.; Bačík, P.; Vaculovič, T.; Galiová, M. Beryl composition and evolution trends: An example from granitic pegmatites of the beryl-columbite subtype, Western Carpathians, Slovakia. J. Geosci. 2010, 55, 69-80. [CrossRef]

12. London, D. Reading Pegmatites: Part 1-What Beryl Says. Rocks Miner. 2015, 90, 138-153. [CrossRef]

13. Grew, E.S. Mineralogy, Petrology and Geochemistry of Beryllium: An Introduction and List of Beryllium Minerals. Rev. Mineral. Geochem. 2002, 50, 1-76. [CrossRef]

14. Cerny, P.; Turnock, A.C. Beryl from the granitic pegmatites at Greer Lake, southeastern Manitoba. Can. Mineral. 1975, 13 , 55-61.

15. Neiva, A.M.R.; Neiva, J.M.C. Beryl from the granitic pegmatite at Namivo, Alto Ligonha, Mozambique. J. Mineral. Geochem. 2005, 181, 173-182. [CrossRef]

16. Linnen, R.L.; Van Lichtervelde, M.; Černý, P. Granitic pegmatites as sources of strategic metals. Elements 2012, 8, 275-280. [CrossRef]

17. Thomas, R.; Webster, J.D.; Davidson, P. Be-daughter minerals in fluid and melt inclusions: Implications for the enrichment of Be in granite-pegmatite systems. Contrib. Mineral. Petrol. 2011, 161, 483-495. [CrossRef]

18. Evensen, J.M.; London, D. Experimental silicate mineral/melt partition coefficients for beryllium and the crustal Be cycle from migmatite to pegmatite. Geochim. Cosmochim. Acta 2002, 66, 2239-2265. [CrossRef]

19. Rao, C.; Wang, R.C.; Hu, H. Paragenetic assemblage of beryllium silicates and phosphates from the Nanping granite pegmatite dyke; Fujian province southeastern China. Can. Mineral. 2011, 49, 1175-1187. [CrossRef]

20. Schilling, J.; Bingen, B.; Skar, Q.; Wenzel, T.; Markl, G. Formation and evolution of the Høgtuva beryllium deposit, Norway. Contrib. Mineral. Petrol. 2015, 170,1-21. [CrossRef]

21. Lyalina, L.M.; Selivanva, E.A.; Zozulya, D.; Ivanyuk, G.Y. Beryllium mineralogy of the Kola Peninsula, Russia-A review. Minerals 2019, 9, 12. [CrossRef]

22. London, D.; Kontak, D.J. Granitic Pegmatites: Scientific Wonders and Economic Bonanzas. Elements 2012, 8, 257-261. [CrossRef]

23. Glover, A.S.; Rogers, W.Z.; Barton, J.E. Industrial Minerals. Elements 2012, 8, 269-274. [CrossRef]

24. Černý, P.; London, D.; Novák, M. Granitic pegmatites as reflections of their sources. Elements 2012, 8, 289-294. [CrossRef]

25. Tkachev, A.V. Evolution of metallogeny of granitic pegmatites associated with orogens throughout geological time. Geol. Soc. London Spec. Publ. 2011, 350, 7-23. [CrossRef]

26. Sheikhi, F.; Alaminia, Z.; Tabakh Shabani, A.A. Seranjic skarn geothermomtery (SW Ghorveh, Kurkistan province). Iran. J. Crystallogr. Mineral. 2012, 20, 343-354.

27. Samadi, R.; Miller, N.R.; Mirnejad, H.; Harris, C. Origin of garnet in aplite and pegmatite from Khajeh Morad in northeastern Iran: A major, trace element, and oxygen isotope approach Ramin. Lithos 2014, 208, 378-392. [CrossRef]

28. Sepahi, A.A.; Salami, S.; Lentz, D.R.; McFardand, C.R.M. Petrography, Geochemistry, and U-Pb Geochronology of Pegmatites and Aplites Associated with the Alvand Intrusive Complex in the Hamedan Region, Sanandaj-Sirjan Zone, Zagros Orogen (Iran). Int. J. Earth Sci. 2018, 107, 1059-1096. [CrossRef]

29. Azizi, H.; Nouri, F.; Stern, R.J.; Azizi, M.; Lucci, F.; Asahara, Y.; Zarinkoub, M.H.; Chung, S.L. New evidence for Jurassic continental rifting in the northern Sanandaj Sirjan Zone, western Iran: The Ghalaylan seamount, southwest Ghorveh. Int. Geol. Rev. 2020, 62, 1635-1657. [CrossRef]

30. Azizi, H.; Mohammadi, K.; Asahara, Y.; Tsuboi, M.; Daneshvar, N.; Mehrabi, B. Strongly peraluminous leucogranite (EbrahimAttar granite) as evidence for extensional tectonic regime in the Cretaceous, Sanandaj Sirjan zone, northwest Iran. Chem. Erde Geochem. 2016, 76, 529-541. [CrossRef]

31. Nouri, F.; Stern, R.J.; Azizi, H. The Jurassic tourmaline-garnet-beryl semi-gemstone province in the Sanandaj-Sirjan Zone, western Iran. Int. Geol. Rev. 2018, 1-25. [CrossRef]

32. Salami, S.; Sepahi, A.A.; Maanijou, M. The study of beryl pegmatites of Ebrahim Attar and related skarn (south west of Ghorveh). In Proceedings of the 23rd, Symposium of Crystallography and Minelogy of Iran, Dagman, Iran, 28-29 January 2013; pp. 825-829.

33. Stöcklin, J. Structural history and tectonics of Iran1: A review. Am. Assoc. Pet. Geol. Bull. 1968, 52, 1229-1258. [CrossRef]

34. Alavi, M. Regional stratigraphy of the Zagros fold-thrust belt of Iran and its proforeland evolution. Am. J. Sci. 2004, 304, 1-20. [CrossRef]

35. Ghasemi, A.; Talbot, C.J. A new tectonic scenario for the Sanandaj-Sirjan Zone (Iran). J. Asian Earth Sci. 2006, 26, 683-693. [CrossRef]

36. Azizi, H.; Zanjefili-Beiranvand, M.; Asahara, Y. Zircon U-Pb ages and petrogenesis of a tonalite-trondhjemite-granodiorite (TTG) complex in the northern Sanandaj-Sirjan zone, northwest Iran: Evidence for Late Jurassic arc-continent collision. Lithos 2015, 216-217, 178-195. [CrossRef]

37. Azizi, H.; Asahara, Y.; Minami, M.; Anma, R. Sequential magma injection with a wide range of mixing and mingling in Late Jurassic plutons, southern Ghorveh, western Iran. J. Asian Earth Sci. 2020, 104469. [CrossRef]

38. Yajam, S.; Scarrow, J.H.; Ghalamghash, J.; Bea, F. The spatial and compositional evolution of the Late Jurassic Ghorveh- Dehgolan plutons of the Zagros Orogen, Iran: SHRIMP zircon U-Pb and Sr and Nd isotope evidence. Geologica Acta 2015, 13, 25-43. [CrossRef] 
39. Azizi, H.; Asahara, Y. Juvenile granite in the Sanandaj-Sirjan Zone, NW Iran: Late Jurassic-Early Cretaceous. Int. Geol. Rev. 2013, 55, 1523-1540. [CrossRef]

40. Sartibi, H. Geological Map of Sanandaj (1/100000); Geological Survey of Iran: Tehran, Iran, 2005.

41. Hosseiny, M.; Mosawery, F.; Karimynia, M. 1:100.000 Geological Map of Ghorveh; Geological Survey of Iran: Tehran, Iran, 1999.

42. Eshraghi, A.A. Geological Map of Iran Sheet 5559-Songhor, Scale 1:100,000; Geological Survey of Iran: Tehran, Iran, 1996.

43. Selway, J.B.; Breaks, F.W.; Road, R.L.; Pe, O.N.; Tindle, A.G. A review of rare-element (Li-Cs-Ta) pegmatite exploration techniques for the Superior Province, Canada, and large worldwide tantalum deposits. Explor. Min. Geol. 2005, 14, 1-30. [CrossRef]

44. Sun, S.S.; McDonough, W.F. Chemical and isotopic systematics of oceanic basalts: Implications for mantle composition and processes. Geol. Soc. London Spec. Publ. 1989, 42, 313-345. [CrossRef]

45. Rollinson, H. Using Geochemical Data: Evaluation Presentation, Interpreation; Routledge: Abingdon, UK, 1993.

46. Bragg, W.L.; West, J. The structure of beryl, $\mathrm{Be}_{3} \mathrm{Al}_{2} \mathrm{Si}_{6} \mathrm{O}_{18}$. Proc. R. Soc. London. Ser. A Contain. Pap. Math. Phys. Character 1926, 111, 691-714.

47. Aurisicchio, C.; Fioravanti, G.; Grubessi, O.; Zanazzi, P.F. Reappraisal of the crystal chemistry of beryl. Am. Mineral. 1988, 73, 826-837.

48. Belov, N.V. Essays on structural mineralogy IX. Miner. Sb. Geol Soc Lvov 1958, 12, 15-42.

49. Thomas, Z.; Link, K. In-situ Rb-Sr dating of beryl. In Proceedings of the Goldschmidt, Barcelona, Spain, 18-23 August 2019 ; p. 1.

50. Groat, L.A. Crystal chemistry of dark blue aquamarine from the true showing, Yukan Territory, Canada. Can. Mineral. 2010, 48, 597-613. [CrossRef]

51. Novák, M.; Filip, J. Unusual (Na, Mg)-enriched beryl and its breakdown products (beryl II, bazzite, bavenite) from euxenite-type NYF pegmatite related to the orogenic ultrapotassic Pluton, Czech Republic. Can. Mineral. 2010, 48, 615-628. [CrossRef]

52. Černý, P.; Menizer, R. Fertile granites in the Archean and Proterozoic fields of rare element pegmatites: Crustal environment, geochemistry and petrogenetic relationships. In Recent Advances in the Geology of Granite-related Mineral Deposits. Can. Inst. Min. Metall. 1988, 39, 170-206.

53. Černý, P. Exploration strategy and methods for pegmatite deposits of tantalum. In Lanthanides, Tantalum and Niobium; Springer: Berlin/Heidelber, Germany, 1989; pp. 274-302.

54. Wilson, M. Review Of Igneous Petrogenesis: Aglobal Tectonic Approach. Terra Nov. 1989, 1, 218-222. [CrossRef]

55. Kesler, S.E.; Gruber, P.W.; Medina, P.A.; Keoleian, G.A.; Everson, M.P.; Wallington, T.J. Global lithium resources: Relative importance of pegmatite, brine and other deposits. Ore Geol. Rev. 2012, 48, 55-69. [CrossRef]

56. Černý, P.; Meintzer, R.E.; Anderson, A.J. Extreme fractionation in rare- element granitic pegmaite: Selected examples of data and nechanism. Can. Mineral. 1985, 23, 381-421.

57. Beal, K.; Lentz, D.R.; Hall, D.C.; Dunning, G. Mineralogical, geochronological and geochemical characterization of Early Devonian aquamarine-bearing dykes of the Zealand Station beryl and molybdenite deposit, west central New Brunswick. Can. J. Earth Sci. 2010, 47, 859-874. [CrossRef]

58. Zhu, Y.; Zeng, Y.; Gu, L. Geochemistry of the rare metal-bearing pegmatite No. 3 vein and related granites in the Keketuohai region, Altay Mountains, northwest China. J. Asian Earth Sci. 2006, 27, 61-77. [CrossRef]

59. Dostal, J.; Chatterjee, A.K. Contrasting behaviour of $\mathrm{Nb} / \mathrm{Ta}$ and $\mathrm{Zr} / \mathrm{Hf}$ ratios in a peraluminous granitic pluton (Nova Scotia, Canada). Chem. Geol. 2000, 163, 207-218. [CrossRef]

60. Steiner, B.M. Tools and workflows for grassroots Li-Cs-Ta (LCT) pegmatite exploration. Minerals 2019, 9, 499. [CrossRef]

61. Watson, E.B.; Harrison, T.M. Zircon saturation revisited: Temperature and composition effects in a variety of crustal magma types. Earth Planet. Sci. Lett. 1983, 64, 295-304. [CrossRef]

62. Acosta-Vigil, A.; London, D.; Morgan, G.B.; Dewers, T. Solubility of excess alumina in hydrous granitic melts in equilibrium with peraluminous minerals at $700-800{ }^{\circ} \mathrm{C}$ and $200 \mathrm{MPa}$, and applications of the aluminum saturation index. Contrib. Miner. Pet. 2003, 146, 100-119. [CrossRef]

63. Yang, X.M.; Lentz, D.R.; Chi, G. Ferric-ferrous iron oxide ratios: Effect on crystallization pressure of granites estimated by Qtz-geobarometry. Lithos 2021, 380-381, 105920. [CrossRef]

64. McDonough, W.F.; Sun, S.-S. The composition of the Earth. Chem. Geol. 1995, 120, 223-253. [CrossRef]

65. Aurisicchio, C.; Conte, A.M. Beryl from miarolotic pockets of granitic pegmatites, Elba, Italy: Characterization of crystal chemistry by means of EMP and SIMS analyses. Can. Mineral. 2012, 50, 1467-1488. [CrossRef]

66. Beus, A.A. Geochemistry of Berllium and Genetic Types of Beryllium Deposits; Freemand and Co.: San Francisco, CA, USA, 1966.

67. Hawthorne, F.C.; Cerny, P. The alkali-metal positions in Cs-Li beryl. Can. Mineral. 1977, 15, 414-421.

68. Markl, G.; Schumcher, J.C. Beryl stability in local hydrothermal and chemical environments in a mineralized granite. Am. Mineral. 1997, 82, 194-202. [CrossRef]

69. Cerny, P.; Anderson, A.J.; Tomascak, P.B.; Chapman, R. Geochemical and morphological features of beryl from the Bikita granitic pegmatite, Zimbabwe. Can. Mineral. 2003, 41, 1003-1011. [CrossRef]

70. Wang, R.C.; Che, X.D.; Zhang, W.L.; Zhang, A.C.; Zhang, H. Geochemical evolution and late re-equilibration of Na-Cs-rich beryl from the Koktokay \#3 pegmatite (Altai, NW China). Eur. J. Mineral. 2009, 21, 795-809.

71. Liu, Y.; Deng, J.; Sun, D.; Zhou, Y. Morphology and gensis typomorphism of minerals in W-Sn-Be deposit of Huya, Sichuan. Geosci. J. 2007, 32, 75-81. 
72. Sarbajna, C.; Sinha, R.P.; Krishnamurthy, P.; Krishna, K.V.G.; Viswanathan, R.; Banerjee, D. Metal bearing pegmatite of MarlagallaAllapatna, Mandya district, Karnataka. Geol. Soc. India 1999, 599-608.

73. Trueman, D.L.; Cerny, P. Exploration for rare-element granitic pegmatites. In Proceedings of the Short Course in Granitic Pegmatites in Science and Industry, Winnipeg, MB, Canada, 13-16 May 1982; Mineralogical Association of Canada: Quebec, QC, Canada, 1982; pp. 463-493.

74. Merino, E.; Villaseca, C.; Orejana, D.; Jeffries, T. Gahnite, chrysoberyl and beryl co-occurrence as accessory minerals in a highly evolved peraluminous pluton: The Belvís de Monroy leucogranite (Cáceres, Spain). Lithos 2013, 179, 137-156. [CrossRef]

75. Evensen, J.M.; London, D.; Wendlandt, R.F. Solubility and stability of beryl in granitic melts. Am. Mineral. 1999, 84, 733-745. [CrossRef]

76. Charoy, B. Beryllium speciation in evolved granitic magmas: Phosphates versus silicates. Eur. J. Mineral. 1999, 11, 135-148. [CrossRef]

77. London, D. Pegmatites, the Canadian Mineralogist; Special Publication 10; The Mineralogical Association of Canada: Quebec, QC, Canada, 2008.

78. Wahlberg, J.S.; Fishman, M.J. Adsorption of Cesium on Clay Minerals; US Government Printing Office: Washington, DC, USA, 1962.

79. London, D. Ore-forming processes within granitic pegmatites. Ore. Geol. Rev. 2018, 101, 349-383. [CrossRef]

80. Baker, D.R. Tracer versus trace element diffusion: Diffusional decoupling of Sr concentration from Sr isotope composition. Geochim. Cosmochim. Acta 1989, 53, 3015-3023. [CrossRef]

81. Černý, P. Rare-element granitic pegmatites. Part I: Anatomy and internal evolution of pegmatitic deposits. Geosci. Canada 1991, 11,49-67.

82. Simmons, W. Pegmatology: Pegmatite Mineralogy, Petrology and Petrogenesis; Rubellite Press: New Orleans, LA, USA, 2003. 